CARIM-INDIA - DeVELoPING A KNOWLEDGE BASE FOR POLICYMAKING ON INDIA-EU MIGRATION

Co-financed by the European Union

\title{
Investment and Migration Linkages between India and the EU
}

\section{Deeparghya Mukherjee} Rupa Chanda
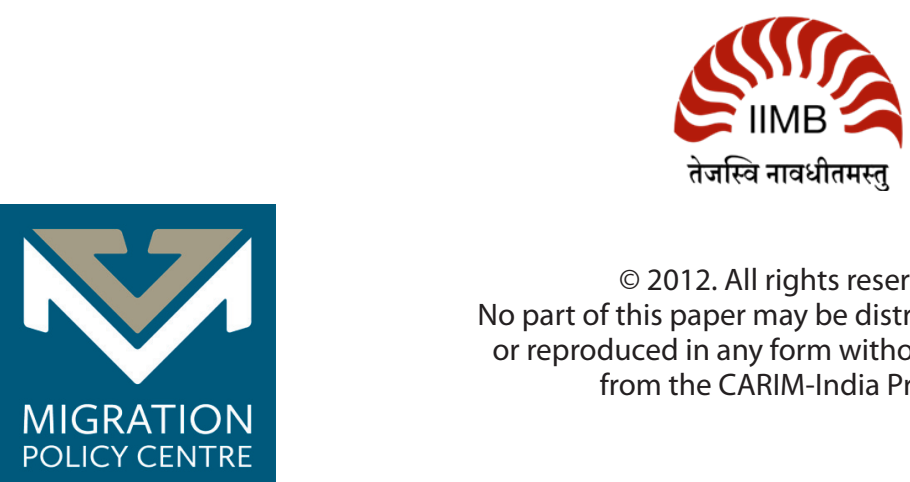
CARIM-India

Developing a knowledge base for policymaking on India-EU migration

Research Report

Thematic Paper

CARIM-India RR2012/16

\section{Investment and Migration Linkages \\ between India and the EU}

Deeparghya Mukherjee ${ }^{(1)}$ and Rupa Chanda ${ }^{(2)}$

Doctoral student of Economics, Indian Institute of Management Bangalore (1)

Professor of Economics, Indian Institute of Management Bangalore (2) 


\title{
(C) 2012, European University Institute \\ Robert Schuman Centre for Advanced Studies
}

This text may be downloaded only for personal research purposes. Any additional reproduction for other purposes, whether in hard copies or electronically, requires the consent of the Robert Schuman Centre for Advanced Studies.

Requests should be addressed to India-EU.Migration@eui.eu

If cited or quoted, reference should be made as follows:

Deeparghya Mukherjee, Rupa Chanda, Investment and Migration Linkages between India and the EU, CARIM-India RR 16, Robert Schuman Centre for Advanced Studies, San Domenico di Fiesole (FI): European University Institute, 2012.

THE VIEWS EXPRESSED IN THIS PUBLICATION CANNOT IN ANY CIRCUMSTANCES BE REGARDED AS THE OFFICIAL POSITION OF THE EUROPEAN UNION

\author{
European University Institute \\ Badia Fiesolana \\ I - 50014 San Domenico di Fiesole (FI) \\ Italy \\ http://www.eui.eu/RSCAS/Publications/ \\ http://www.india-eu-migration.eu/publications/ \\ http://cadmus.eui.eu
}




\section{CARIM-India - Developing a knowledge base for policymaking on India-EU migration}

This project is co-financed by the European Union and carried out by the EUI in partnership with the Indian Council of Overseas Employment, (ICOE), the Indian Institute of Management Bangalore Association, (IIMB), and Maastricht University (Faculty of Law).

The proposed action is aimed at consolidating a constructive dialogue between the EU and India on migration covering all migration-related aspects. The objectives of the proposed action are aimed at:

- Assembling high-level Indian-EU expertise in major disciplines that deal with migration (demography, economics, law, sociology and politics) with a view to building up migration studies in India. This is an inherently international exercise in which experts will use standardised concepts and instruments that allow for aggregation and comparison. These experts will belong to all major disciplines that deal with migration, ranging from demography to law and from economics to sociology and political science.

- Providing the Government of India as well as the European Union, its Member States, the academia and civil society, with:

1. Reliable, updated and comparative information on migration

2. In-depth analyses on India-EU highly-skilled and circular migration, but also on low-skilled and irregular migration.

- Making research serve action by connecting experts with both policy-makers and the wider public through respectively policy-oriented research, training courses, and outreach programmes.

These three objectives will be pursued with a view to developing a knowledge base addressed to policy-makers and migration stakeholders in both the EU and India.

Results of the above activities are made available for public consultation through the website of the project: http://www.india-eu-migration.eu/

For more information:

CARIM-India

Robert Schuman Centre for Advanced Studies (EUI)

Convento

Via delle Fontanelle 19

50014 San Domenico di Fiesole

Italy

Tel: +390554685817

Fax: + 390554685770

Email: India-EU.Migration@eui.eu

\section{Robert Schuman Centre for Advanced Studies}

http://www.eui.eu/RSCAS/ 


\begin{abstract}
India has had long-standing investment ties with various EU countries. Many EU countries are significant investors in India and several EU-based MNCs have business operations in India. Of late, Indian investments in the EU have also gained importance. Leading Indian IT companies have established local presence through branches and subsidiaries in several EU countries. Alongside the growing business relations between India and the EU, there is increased short-term and circular mobility of persons between India and the EU, in large part to support business operations in each other's markets.
\end{abstract}

This paper examines the linkages between investment and associated labour mobility between India and the EU. Following the introduction, Section 2 provides a brief literature review of labour mobility and investment relations and their effects on developed and developing nations. Section 3 offers an overview of growing investment relations between India and the EU and accompanying labour flows between India and the EU to underscore the need for studying this linkage. Section 4 discusses immigration and labour market regulations which have a bearing on investment operations and vice versa, for selected EU countries in order to highlight the extent to which regulations on one impinge on the other. It also examines the Schengen treaty and the implications of recent developments such as the EU Blue Card and totalisation agreements (signed or under negotiation) between India and some EU countries for investment-related labour mobility from India to the EU. Section 5 provides the findings from in-depth interviews conducted with senior industry executives from leading EU as well as Indian firms to understand the nature of the labour flows which accompany investment operations. It also examines the extent to which investment and labour flows in the India-EU context are complementary and how barriers to labour mobility may affect investment operations in each other's market. The discussion in this section indicates that there is considerable short-term mobility of Indian business visitors, intracorporate transferees, and professionals working from Indian subsidiaries of European firms to the EU countries. There is also movement of skilled Indians working in Indian firms in India, to their EU-based subsidiaries. In both cases, movement from India to the EU is mainly driven by the need to address skill shortages in the EU countries and to facilitate the migration and offshoring of client processes to India. The evidence indicates that investment presence in the EU facilitates mobility from India to the EU, although there are considerable differences in labour market and investment regulations across the different EU member countries. Section 6 examines the nature of movement by EU nationals to Indian subsidiaries of EU MNCs and the associated Indian immigration policies affecting such movement. The discussion indicates that such movement is very limited at present, mostly pertaining to business meetings and training sessions and the problems encountered mostly pertain to issues of transparency, poor institutional mechanisms and delays. Section 7 concludes by noting the main issues concerning labour mobility that would need to be addressed to promote India-EU investment relations. 


\section{Introduction}

In the last few decades the world has witnessed shifts in economic policies that have impacted the investment climate across the globe. Asian economies like India have liberalised their previously protected economies relaxing their Foreign Direct Investment (FDI) regulations. While India remained closed to foreign investment till 1990, the post 1990 period saw the gradual relaxation of FDI regulations in most sectors. Economic liberalisation supplemented with investor friendly policies saw India emerge as one of the world's most favourable investment destinations. ${ }^{1}$ The increased integration of the Indian economy through investment ties has led to a growing need for transfer of employees from India to the investor countries and vice versa to ensure successful implementation of firm level strategies. Although emigration from India to Western countries for purposes of study and work were known phenomena, the demand for short-term transfers has increased with globalisation. With the onset of offshoring and the need to understand client markets and requirements for successful execution of offshoring contracts, the need for short-term inter- country transfer of professionals has increased further. The emergence of India as an economic power that is now also investing in developed countries has further added to this growing need for employee mobility across geographies.

The growth story of most countries in the last century has taken the route of foreign investments and international trade. Most of the big firms in the world today are multinational corporations (MNCs) with operations spread across the globe. The importance of foreign investment and trade is also evident from the large number of bilateral investment and trade agreements that have been signed across countries. The North American Free Trade Agreement (NAFTA) is a classic example of a preferential trade agreement between Mexico, Canada and the United States. However, trade agreements or investment agreements alone may be of little consequence in fostering growth if labour mobility arrangements are fragmented. It is especially in this respect that one observes special labour mobility arrangements between the NAFTA countries. The ease of trading services in the present day has further increased the importance of labour mobility for investment and trade relations to reap the full benefits. Special mention must be made of services trade through modes 3 and 4 which cater to serving a foreign country through commercial presence and temporary movement of workers, respectively. It is in this light that studying investment and labour mobility inter-linkages and trends becomes important.

India and the European Union (EU) member countries have historically fostered long-term economic relations through international trade. Various EU countries like the UK, Germany, France and Netherlands have historically had investment ties with India, in order to avail of India's huge market as well as benefit from its lower labour costs of production. More recently, many Indian companies have begun to invest in the EU countries in order to serve the EU markets better through local presence and with the objective of acquiring European companies. In 2010, EU investments in India amounted to $€ 3.0$ billion and investments from India in the EU amounted to $€ 0.6$ billion. $^{2}$ These investment relations have been accompanied by growing short-term employee transfers between India and the EU.

In this paper an attempt is made to understand the investment and labour mobility linkages between India and the EU. The respective investment and labour immigration regulations are traced alongside statistics on investment as well as short and long term immigration flows between the two sides. Indepth interviews conducted by the authors are used to identify key features of the investment and labour mobility linkages. In this context, the Schengen treaty and the Blue card scheme for migration of skilled professionals to the EU are analysed. A detailed analysis of country specific visa regimes for

\footnotetext{
${ }^{1}$ See , Ministry of External Affairs (March, 2007), http://www.indiainbusiness.nic.in/Book.pdf) (accessed $7^{\text {th }}$ December, 2011)

2 See European Commission page on Trade for India, http://ec.europa.eu/trade/creating-opportunities/bilateralrelations/countries/india/ (accessed $11^{\text {th }}$ October, 2011)
} 
India and the EU and their respective problems as well as advantages with regard to India-EU investment relations is presented.

This paper is organised as follows: Section 2 offers a literature review of the welfare effects of foreign investment and labour mobility and the role of Bilateral Investment Treaties (BITs) and labour mobility as complementary paths to achieving increased economic welfare. Section 3 discusses the Investment regulations for some EU countries which are the principal investors in India. It analyses the FDI restrictiveness and ease of doing business indicators for selected EU countries and for India. Section 4 analyses the immigration guidelines in some EU countries and also the Schengen Treaty regarding recent short-term immigration by different types of workers from India. Section 5 outlines the profile of Indian professionals and the purposes for which they visit the EU. This is followed by the findings of in-depth interviews conducted by the authors to highlight the key features and differences across the immigration regimes of different EU countries. Section 6 analyses the transfer of European professionals to India and the issues faced in dealing with Indian immigration formalities. Section 7 concludes the paper.

\section{Review of the Literature on Investment and Mobility}

The importance of foreign direct investment (FDI) as a mutually beneficial phenomenon for both home and host countries has been documented extensively in the academic literature. From the point of view of firms, FDI has had profitability objectives and has traditionally taken either of two forms: Horizontal and Vertical. Horizontal FDI has been favoured by firms seeking to replicate production processes across geographies in order to exploit the host country's market with products similar to the ones produced for the home market. ${ }^{3}$ On the other hand vertical FDI has primarily been undertaken by MNCs to take advantage of lower production costs in host geographies to vertically integrate the firm, giving rise to intra-firm trade in intermediates. ${ }^{4}$ Vertical integration/vertical FDI has been studied at length theoretically. ${ }^{5}$ Dunning (1981b and 1988a) outlines the necessary conditions for international production by a firm: (a) The firm should have ownership specific advantages (b) In order to exploit those advantages to the greatest extent, presence in the foreign destination must be more beneficial than merely exporting products from home and (c) Overseas locational factors ought to be more favourable than home country. Markusen \& Maskus (2001) show that falling trade costs may either foster or hamper FDI (both horizontal i.e., market seeking and vertical i.e., cost saving) depending on country characteristics.

From the point of view of the host countries receiving FDI, existing literature documents the impact on economic development. In particular, most FDI receiving countries have been the traditional less developed economies and emerging economies. These are labour surplus countries which attract foreign investors through lower costs of production. The economies have been capital constrained and stand to gain from foreign investments and associated employment opportunities for the surplus labour force. The economic development role of FDI has been emphasized by a significant body of literature. ${ }^{6}$

In addition to FDI, international labour mobility has been documented as an efficient way to accelerate development of the LDCs. Mills (1929[1848]) suggested that transfer of resources both labour and capital, from countries of lower returns to those of higher returns maximises world

\footnotetext{
${ }^{3}$ See Markusen (1984) and Barba et. al (2004)

${ }^{4}$ Yeats (2001) and Borga and Zeile (2004)

${ }^{5}$ Grossman and Helpman (2003 and 2004), Hummels, Ishii and Yi (2001), Humels, Rapopot and Yi (1998) and McLaren (2000)

${ }^{6}$ Dunning (1981a), Gray (1985), Dunning and Cantwell (1990) and Ozawa (1979)
} 
production. Amidst claims of "brain drain" theories of migration", a competing body of literature suggests that a threshold level of emigration does not affect the welfare of the developing country. ${ }^{8}$ Some studies such as Mountford (1997) also show that a moderate level of emigration may actually benefit developing countries. These benefits may take various forms, including "brain circulation" whereby skilled individuals return to the country of origin after working in the foreign country and raise domestic productivity; ${ }^{9}$ remittances from skilled and less skilled migrant workers and resulting multiplier effects through increased domestic demand; ${ }^{10}$ and technology transfer. ${ }^{11}$ However, notwithstanding the many recognised benefits of labour mobility, in practice, free labour movement between developed and developing world remains a problematic and sensitive issue. Walmsley \& Winters, (2005) empirically estimate the costs of labour immigration quotas by developed countries and argue that labour mobility restrictions have a far higher cost to the world than trade and capital mobility restrictions. Clemens (2010) suggests that immigration policies need serious consideration from the developed world if meaningful global integration is to be achieved.

The economic literature also documents the complementary nature of foreign investment and labour mobility to facilitate growth and development. ${ }^{12}$ As noted in Iredale (1999) and Stahl (1993), much of international migration is in effect associated with capital mobility. Iredale (2001) argues that the internationalisation of firms must be supported by the internationalisation of skilled labour. Additionally, a case is made for mobility of MNC employees for professional training purposes. The literature also addresses the role of bilateral investment agreements in facilitating international trade and labour mobility. Nunnenkamp \& Pant, (2003) suggest the growing need for developing countries to bargain for greater labour mobility in response to demands for relaxing FDI restrictions and to be granted treatment at par with local entrepreneurs by the developed countries under bilateral investment treaties. Capital mobility has been seen to be as important as labour mobility in economic integration arrangements. Hoekman and Saggi (2000) and Kumar (2001) have highlighted the possibility of increased asymmetry between developed and developing worlds if free capital movement is not matched by free labour movement.

The GATS negotiations have also stressed the importance of labour mobility for welfare and as a complement to capital mobility. Young (2000) and Panagariya (1999) have further argued that developing countries should only sign investment agreements with the developed countries if the latter are willing to allow easier labour migration from the developing to the developed world. To support his argument Panagariya (1999) used the findings of Hamilton \& Walley (1984) who conclude that the gains from labour mobility are far higher than from any other form of liberalisation and that easing of labour mobility restrictions is of great importance in the context of North-South integration. Rodrik (2002) echoes the views of Panagariya and suggests that countries move in favour of temporary visas to increase both skilled and less skilled migration from developing to developed countries to complement foreign investment.

In her analysis of various RTAs, Chanda (2011) outlines that increasingly economic integration arrangements are addressing issues of labour mobility. However, the approach differs across RTAs. Two different approaches noted in this regard are: (1) Offering broad mobility but applying special rules to selected sectors or exclusion of some sectors from the purview of labour mobility provisions; and (2) Limiting labour mobility to certain groups of service suppliers while covering all sectors. The primary focus remains on mobility related to certain kinds of trade and investment activities only. The

\footnotetext{
${ }^{7}$ See, Bhagwati and Hamada (1973)

${ }^{8}$ See, Johnson (1967) and Grubel and Scott (1966)

${ }^{9}$ Johnson and Regets (1998)

${ }^{10}$ Taylor and Adelman (1995)

${ }^{11}$ Teferra (2000)

${ }^{12}$ Panagariya (1999) and Mody (2004)
} 
prevalence of short-term labour mobility of selected professionals (having specific skill sets relevant to the RTA) is easily observed; e.g., ASEAN and EU-Mexico for financial services. Some RTAs offer special visa schemes to manage entry; e.g., Trade NAFTA Visa and APEC Business travel Card. Some agreements allow access under existing visa schemes; e.g., APEC and SAARC. In the context of India and the European Union, a prospective FTA is under negotiation. While the EU has been largely pushing India to liberalise trade in goods and services (especially through FDI presence), India has been negotiating for greater labour mobility. The negotiations have been underway since 2005, with the completion of around fourteen rounds as of February 2012. The agreement is expected to be signed by the end of 2012 (though that seems unlikely in view of the current state of affairs in the EU and the difficulties encountered in these negotiations). ${ }^{13}$

From the literature cited above, it is clear that studying investment and associated labour mobility linkages is important. This paper addresses this subject in the context of India-EU investment and labour mobility relations. The next section identifies the EU countries which have invested the most in India between 2000 and 2010. This is followed by a discussion on the FDI restrictiveness patterns across time. The discussion also highlights the nature of the companies (industry) investing in India followed by a similar analysis of Indian companies investing in the EU.

\section{Investment Flows and Regulations}

India has for long been a favourable investment destination for many countries in the EU predominantly for the UK for historical reasons. Recently, Indian investments in the EU have picked up with various Indian companies especially in the IT, ITeS sector investing in EU countries. Given the role of investments and labour mobility for both developed and developing nations as delineated above through the review of academic literature, it is worth studying in some detail the role of labour mobility in shaping India-EU investment relations.

Based on the latest trends in FDI inflows from the EU countries to India, Germany, the UK, France, Italy and Belgium emerge as the principal EU investors in India. The figure below traces the flow of FDI by selected EU countries to India between 2000 and 2010.

Figure 1. Yearly FDI inflows by major EU investor countries

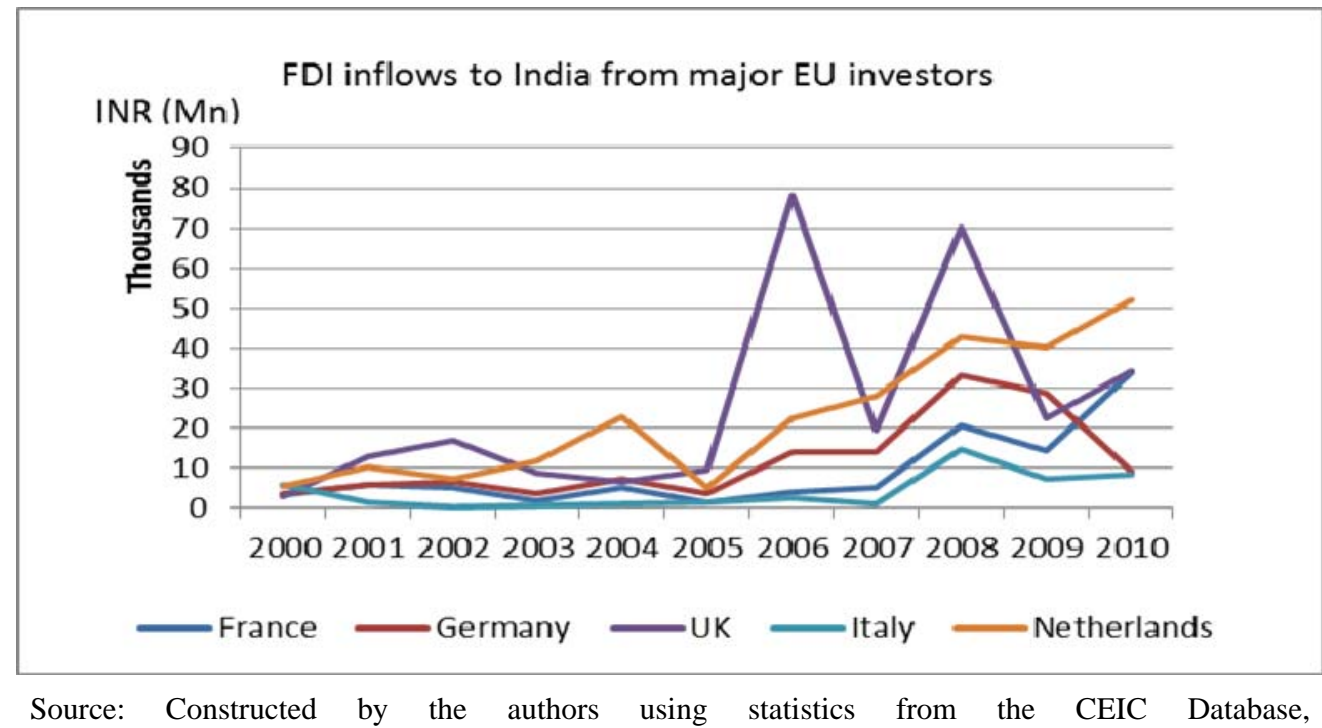

http://www.ceicdata.com/ (accessed 30 ${ }^{\text {th }}$ September, 2011)

\footnotetext{
${ }^{13}$ Further discussion of the prospects for liberalizing labour mobility under the prospective India-EU Trade and Investment Agreement is left to another paper specifically focusing on this agreement and the status of negotiations therein.
} 
An examination of the statistics also reveals Cyprus to be one of the top investors in terms of total FDI flowing into India from the EU between 2000 and 2010. The latter is due to the tax incentives for investment from Cyprus and a double taxation treaty between India and Cyprus which incentivises investment in India. ${ }^{14}$ It is thus not included in the above figure.

The investment regulations in terms of FDI guidelines are the business environment as captured by way of "Doing Business Indicators" are highlighted for selected EU countries in the discussion that follows. Figure 2 shows the FDI restrictiveness index for some EU countries and India.

Figure 2. FDI Restrictiveness Index for Select EU countries and India

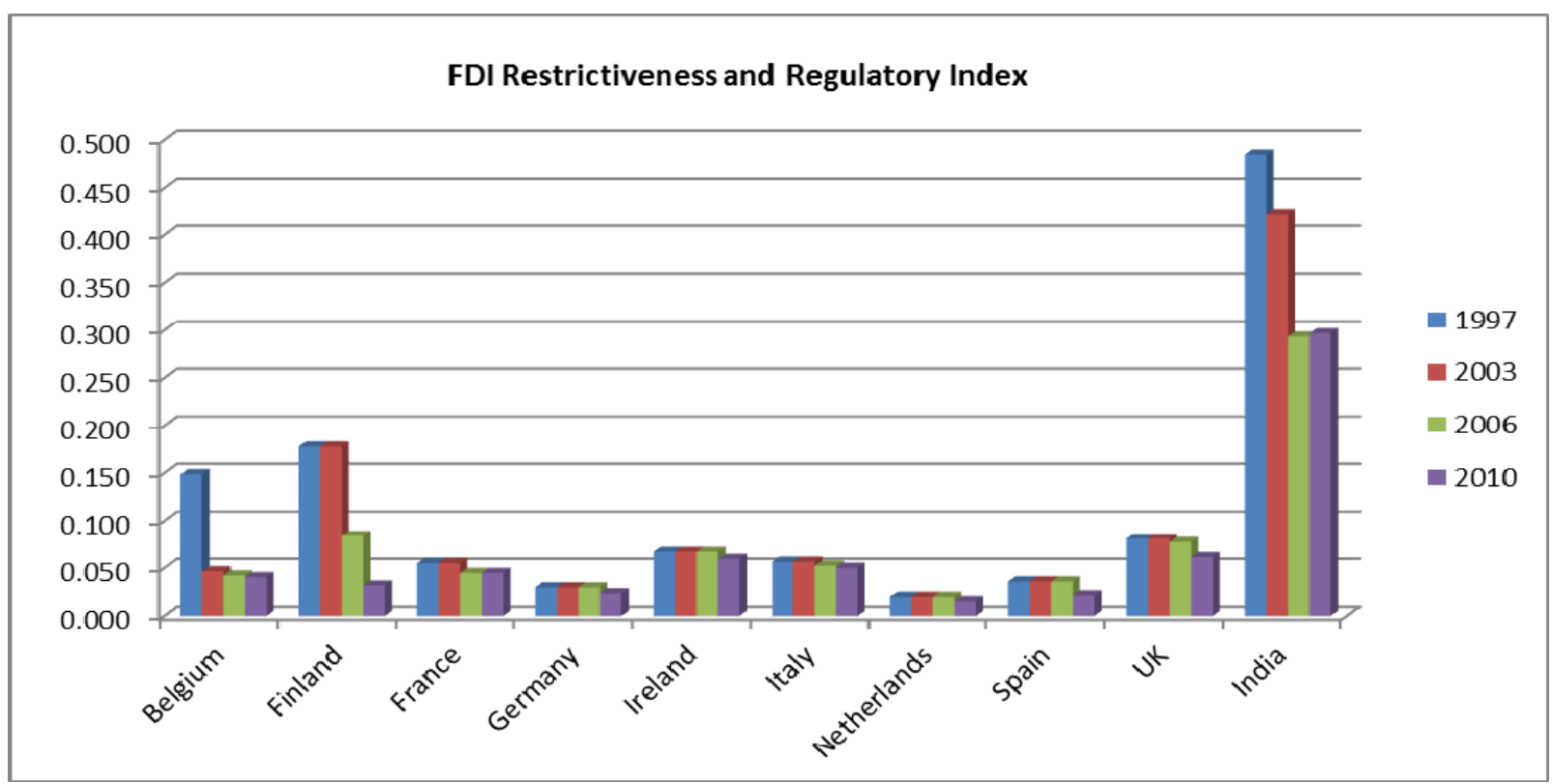

Source: Compiled by the authors based on Kalinova, Palem and Thomsen (2010) and the OECD FDI Regulatory Restrictiveness (RR) Index ${ }^{15}$

It is clear from the above figure that most EU countries have reduced barriers to capital inflows over the last decade. Most EU countries allow foreign investment in all sectors except for (1) restrictions due to national security concerns and (2) restrictions in public interest. ${ }^{16}$ India has also lowered FDI restrictiveness significantly over the last two decades.

Table 1 shows the ease of doing business rankings for some of the EU countries and India. While India has increased the ease of doing business over the last few years, the scene has been mixed for the EU countries. While on one hand, countries like Germany, France and Norway have improved their ranking, on the other hand countries like Italy, Belgium and Spain have moved lower in the rankings. Ireland and the UK have almost remained unchanged with respect to the ease of doing business.

\footnotetext{
${ }^{14}$ See, Eurofast (2011)

15 The index is based on four distinct factors, namely: (i) foreign equity restrictions, screening and prior approval requirements, (iii) rules for key personnel \& (iv) other restrictions on the operation of foreign enterprises. The index covers 22 sectors and aggregates over scores on each of the above parameters. The highest value is 1 signifying full restriction on foreign investments and lowest value is zero denoting no impediments to FDI. See Appendix I in Kalinova, Palem and Thomsen (2010)

${ }^{16}$ See US Government Accountability Office (2008), Table 1, p. 8
} 
Table1. Ease of doing Business for Select EU Countries and India

\begin{tabular}{|l|r|r|r|}
\hline \multicolumn{4}{|c|}{ Ease of doing business (Rank) } \\
\hline Country & $\mathbf{2 0 0 7}$ & $\mathbf{2 0 1 1}$ & $\mathbf{2 0 1 2}$ \\
\hline Belgium & 20 & 27 & 28 \\
\hline France & 35 & 26 & 29 \\
\hline Germany & 21 & 19 & 2 \\
\hline Ireland & 10 & 8 & 10 \\
\hline Italy & 82 & 83 & 37 \\
\hline Netherlands & 22 & 29 & 6 \\
\hline Norway & 9 & 7 & 44 \\
\hline Spain & 39 & 45 & 14 \\
\hline Sweden & 13 & 9 & 7 \\
\hline UK & 6 & 6 & 132 \\
\hline India & 134 & 139 & \\
\hline
\end{tabular}

Source: Compiled by the authors from World Bank data

http://www.doingbusiness.org/ /media/FPDKM/Doing\%20Business/Documents/Annual-Reports/English/DB07-

FullReport.pdf and http://www.doingbusiness.org/data (accessed $22^{\text {nd }}$ November, 2011)

An examination of the sectoral profile of EU companies investing in India indicates that the MNCs primarily belong to the engineering (electronic, electrical, construction), automobiles, financial \& banking, fast moving consumer goods (FMCG) sectors. These MNCs have had professional relations with India for many years. The incidence of EU investments in India has increased significantly since 1991 when India embarked on its economic liberalisation programme and gained a further boost post 1998 after the second generation reforms. Some of the biggest EU companies with investment presence in India include Philips, Siemens, Deutsche Bank, HSBC Bank, Volkswagen etc.

Indian investments in the EU have also increased in the post 2000 period, in the aftermath of the IT revolution and the onset of outsourcing. Many Indian companies working on IT related projects for their clients in the EU have set up branches or subsidiaries in the EU to serve customers better. Chanda(2008) documents that the EU accounted for around 25\% of the international revenues of Indian companies such as Infosys, MindTree, Wipro and TCS. Additionally, there have been multiple acquisitions of a few EU companies by Indian corporate houses leading to substantial FDI from India to the EU. According to Chanda (2008), Indian companies such as Wipro, TCS, Sasken Communications Technologies and more recently TATA Steel have acquired small to large companies in the EU.

\section{EU Immigration Regulations}

The previous section has examined the FDI and business environment in the EU and India. We next examine the latest trends in labour mobility from India to some EU countries. Tables 2 and 3 show the number of short-term work permits and first time permits issued by selected EU countries in recent years. The data reveal no specific trend in the pattern of work visas. The number of work permits issued is quite low though the data indicate that in recent years, the immigration of highly skilled workers has gone up across EU countries. 
Table 2. Three to Five month Work Permits to Indians by type of workers

\begin{tabular}{|l|r|r|r|r|r|r|r|r|}
\hline & \multicolumn{2}{|l|}{ Highly Skilled Workers } & \multicolumn{2}{|c|}{ Researchers } & \multicolumn{2}{c|}{ Seasonal Workers } & \multicolumn{2}{c|}{ Other activities } \\
\hline Country & 2008 & 2009 & 2008 & 2009 & 2008 & 2009 & 2008 & 2009 \\
\hline Germany & 0 & 0 & 0 & 0 & 0 & 0 & 203 & 289 \\
\hline France & 1 & 2 & 5 & 7 & 0 & 0 & 25 & 11 \\
\hline Italy & $:$ & $:$ & 0 & 0 & 1,856 & 691 & 450 & 194 \\
\hline Sweden & $:$ & 339 & 7 & 16 & 0 & 0 & 417 & 228 \\
\hline
\end{tabular}

Source: Compiled by the authors based on data from the Eurostat database,

http://epp.eurostat.ec.europa.eu/portal/page/portal/statistics/search_database (accessed $16^{\text {th }}$ August, 2011)

Note: “:” implies that the data is missing.

Table 3. First permits issued to Indians by Work Type

\begin{tabular}{|c|c|c|c|c|c|c|c|c|}
\hline \multirow[b]{2}{*}{ Country } & \multicolumn{2}{|c|}{ Highly Skilled Workers } & \multicolumn{2}{|c|}{ Researchers } & \multicolumn{2}{|c|}{ Seasonal Workers } & \multicolumn{2}{|c|}{ Other activities } \\
\hline & 2008 & 2009 & 2008 & 2009 & 2008 & 2009 & 2008 & 2009 \\
\hline Germany & 4 & 7 & 5 & 7 & 0 & 0 & 2,707 & 2,134 \\
\hline Italy & : & : & 7 & 18 & 1,856 & 3,951 & 12,149 & 17,868 \\
\hline Belgium & 1,658 & 645 & 0 & 0 & 0 & 0 & 320 & 709 \\
\hline France & 188 & 367 & 249 & 277 & 0 & 0 & 603 & 269 \\
\hline Netherlands & 2,116 & 1,585 & 7 & 69 & : & : & 98 & 137 \\
\hline Sweden & : & 1,638 & 59 & 103 & 0 & 0 & 2,960 & 1,263 \\
\hline UK & 1,717 & 5,409 & : & : & : & : & 28,638 & 21,665 \\
\hline
\end{tabular}

Source: Compiled by the authors based on data from the Eurostat database,

http://epp.eurostat.ec.europa.eu/portal/page/portal/statistics/search_database (Accessed $16^{\text {th }}$ August, 2011)

Note: “:” implies that the data is missing.

Table 4 shows the tier 2 work permits issued by the UK to Indian citizens by category of permit. India as a country receives the highest number of such visas year on year from the UK. The UK is also the most significant investment partner for India amongst the EU countries.

Table 4. UK Tier 2 visas by channel of entry

\begin{tabular}{|c|c|c|c|c|c|c|}
\hline \multicolumn{7}{|c|}{ UK tier 2 visas } \\
\hline Channel of entry & \multicolumn{2}{|c|}{ RLTM $^{\text {a/ }}$} & \multicolumn{2}{|c|}{ ICT $^{\mathbf{b} /}$} & \multicolumn{2}{c|}{ Short $^{\mathbf{c}^{\prime}}$} \\
\hline Year & $\#$ & $\%$ (of Total) & $\#$ & $\%$ (of Total) & $\#$ & $\%$ (of Total) \\
\hline 2009 & 3,947 & $20.9 \%$ & 19,633 & $67.1 \%$ & 1,665 & $28.5 \%$ \\
\hline 2010 & 2,314 & $24.1 \%$ & 12,301 & $67.3 \%$ & 1,598 & $35.3 \%$ \\
\hline
\end{tabular}

Source: Compiled by the authors from OECD (2010), "International Migration and the United Kingdom" Report of the United Kingdom SOPEMI correspondent to the OECD, (Accessed: 18th November, 2011)

Notes:

a/ RLTM: Resident Labour Market Test, b/ ICT: Intracompany Transfer, c/SO: Shortage Occupation 


\subsection{Work Permits in the EU}

This section offers an overview of the work permit and residence visa formalities the EU. This is done at two levels. First, we outline the work permit procedures of countries which are the most important in the realm of India-EU investment and labour mobility relations. Second, the Schengen Treaty is discussed with an outline of the types of visas available and the formalities involved in obtaining them.

\subsubsection{Visa Regulations in Selected EU countries}

The two most important visa categories of interest in the context of investment presence are:

1. Business Visa

2. Work/Employment Visa

Most countries require a separate residence permit apart from a work visa to stay and work in their territory. The visa regulations and formalities vary from country to country within the EU and hence a broad view of country wise visa regulations is offered below for some of the main investors. The countries covered below include: United Kingdom, Germany, France, Netherlands and Italy.

i. $\quad$ United Kingdom (UK)

The UK has a very streamlined procedure for immigration. The number of categories under which visas are available clearly bring out the different implications that each category has for the UK. In terms of work visas the UK offers 5 tiers with subcategories drilled down by type of immigration. Table 5 offers an overview of the types of visas and the profile of work or business they are related to. 
Table 5. UK Visa Categories and Details

\begin{tabular}{|c|c|c|c|}
\hline Visa Type & Tier & Categories & Eligible Individuals \\
\hline \multirow[t]{10}{*}{ Work/ Employment } & 1 & & $\begin{array}{l}\text { Employment-based } \\
\text { immigration }\end{array}$ \\
\hline & & & $\begin{array}{l}\text { Highly skilled migrants, } \\
\text { entrepreneurs, investors, and } \\
\text { foreign graduates of UK } \\
\text { educational institutions }\end{array}$ \\
\hline & 2 & General & $\begin{array}{l}\text { Skilled workers coming to UK } \\
\text { with job offers that cannot be } \\
\text { filled by existing settled UK } \\
\text { Employees }\end{array}$ \\
\hline & & Intra Company Transfers & $\begin{array}{l}\text { Employees of MNCs who are } \\
\text { being transferred to a UK } \\
\text { based branch }\end{array}$ \\
\hline & & Sports People & $\begin{array}{l}\text { Elite sportsmen or coaches } \\
\text { whose will make significant } \\
\text { contribution to their sport }\end{array}$ \\
\hline & & Ministers of Religion & $\begin{array}{l}\text { People who come to fill a } \\
\text { vacancy as a missionary } \\
\text { member or minister of religion } \\
\text { or member of a religious order }\end{array}$ \\
\hline & 3 & & Unskilled temporary Migration \\
\hline & 4 & & Students \\
\hline & 5 & & $\begin{array}{l}\text { Temporary workers from } \\
\text { countries with which the UK } \\
\text { has some prior arrangements }\end{array}$ \\
\hline & & & $\begin{array}{l}\text { A citizen of a participating } \\
\text { company; or a British overseas } \\
\text { citizen; or a British overseas } \\
\text { territory citizen; or a British } \\
\text { national (overseas) }\end{array}$ \\
\hline \multirow[t]{6}{*}{ Business } & & Entrepreneurs & \\
\hline & & Investors & \\
\hline & & Sole representative of overseas company & Employers \\
\hline & & Sole representative of overseas company & Employees \\
\hline & & EC Association Agreement & Only for Bulgaria and Romania \\
\hline & & Freelance in the UK & Only for Bulgaria and Romania \\
\hline
\end{tabular}

Source: Constructed by the authors with inputs from http://www.workpermit.com/uk/uk.htm (accessed 25th September, 2011) 
Of the above outlined categories, the Tier 2 General and intra company transfers categories are currently the most in use for transferring individuals travelling for work purposes to the UK from India.

ii. Germany

In the aftermath of the German Immigration Act, 2005, Germany has endorsed a policy to encourage skilled workers from around the world to move into Germany. The professions mainly in demand are: professors, scientists, engineers and high technology professionals.

In terms of visas related to work or business the following categories of German Visas are easily discernible:

Table 6. German Visa Categories and Description

\begin{tabular}{|l|l|}
\hline Visa Type & Description \\
\hline General Employment Work Permit & $\begin{array}{l}\text { Standard Visa issued to individuals with a job offer from a } \\
\text { German Business }\end{array}$ \\
\hline Specialist Professional Work Permit & $\begin{array}{l}\text { Visa for skilled professionals including university teachers, } \\
\text { individuals with special training, experienced managers etc. }\end{array}$ \\
\hline EU Nationals Work Visa & $\begin{array}{l}\text { Most EU nationals do not require to apply for a German } \\
\text { Work visa with the exception of some EU countries who }\end{array}$ \\
\hline "Van Der Elst” Work Permit & $\begin{array}{l}\text { This is like the intra-company transfer of UK. Helps } \\
\text { German companies to move staff into Germany for work } \\
\text { purposes }\end{array}$ \\
\hline Self Employed Work Permit & $\begin{array}{l}\text { For individuals seeking to start a business in Germany : } \\
\text { requires detailed business plans }\end{array}$ \\
\hline
\end{tabular}

Source: Compiled by the authors with details from http://www.globalvisas.com/germany_visa/german_work_visa.html (accessed 25th September 2011)

Apart from this, Germany, unlike the UK is a signatory to the Schengen Agreement (which we cover in detail later). This facilitates professionals holding a Schengen Visa to travel within the Schengen countries primarily for work purpose, normally for a period of upto ninety days.

\section{iii. France}

France has a host of visa categories under the work visa, to help separate visa categories by type of work. A brief idea of the visa categories can be formed from the table below which lists the types of visas and eligible individuals: 
Table 7. French Visa Types and Description

\begin{tabular}{|l|l|}
\hline Visa Type & Description \\
\hline Skills and Talent Permit & $\begin{array}{l}\text { Allows Visitors to carry out work under their } \\
\text { specialised project. This can be used by entrepreneurs } \\
\text { to travel on business purposes }\end{array}$ \\
\hline Salaried temporary Work Permit & $\begin{array}{l}\text { Applies to individuals of different professions who can } \\
\text { apply and obtain a work permit through this }\end{array}$ \\
\hline Employee on assignment/Secondment Permit & $\begin{array}{l}\text { Applies to non-French companies who want to transfer } \\
\text { employees to France to service clients Issued for a } \\
\text { maximum period of 18 months may be extended } \\
\text { another 9 months }\end{array}$ \\
\hline Seasonal Worker Permit & $\begin{array}{l}\text { Applies to senior managers and executives of a French } \\
\text { company which is a part of an international group with } \\
\text { a minimum salary base. A residence permit of up to } \\
\text { three years is issued }\end{array}$ \\
\hline Scientific Permit & $\begin{array}{l}\text { Applies to workers engaged in seasonal activities for } \\
\text { more than three months. A residence permit valid for } \\
\text { three years is issued with extension for up to six } \\
\text { months possible }\end{array}$ \\
\hline
\end{tabular}

Source: Compiled by the Authors with inputs from http://www.globalvisas.com/visa_france/work_visa_france.html and http://www.parislawyer.fr/gifs/pdf/ComingtoWorkinFrance.pdf (accessed 25th September, 2011)

It is clear from the above that French work permits are differentiated by type of work and even have categories for seasonal work and separate provisions for senior executives which are distinct from the business visa. Reports suggest that entrepreneurs travelling on business needs may be using the first category "Skills and Talent Permit" for business purposes as that even allows them the option of bypassing the labour office which has a role to play in the 'other visas'. ${ }^{17}$

France is a signatory to the Schengen treaty and hence individuals with Schengen Visas can work in France as per the visa conditions.

\section{iv. Netherlands}

Visa categories in Netherlands are not as well defined as in the above countries. It is also recognised that obtaining work permits in Netherlands is more difficult and any Dutch employer seeking to employ a foreigner has to go through the labour office to first advertise the position in most media forums and then apply for a work permit. However, like Germany, Netherlands also recognises and issues Van der Elst work permit, which allows a Dutch company to transfer foreign employees (who have been with the company for at least twelve months in another country) to Netherlands for a maximum period of six months for work purposes. Additionally, Netherlands also has the working holiday visas where young citizens (18-30 years) of select countries like New Zealand, Canada and Australia are allowed to stay in the Netherlands for twelve months and are allowed to work to finance the expenses. Finally, Netherlands is also covered under the Schengen Treaty like Germany, France and Italy.

\footnotetext{
${ }^{17}$ See Wise, “Coming to Work in France: French Work Visas Streamlined”, http://www.parislawyer.fr/gifs/pdf/ComingtoWorkinFrance.pdf (accessed $4^{\text {th }}$ November, 2011)
} 
v. Italy

Immigration into Italy for work is a relatively cumbersome procedure. Work permits may be obtained under two separate categories namely

1. Within the Quota System and

2. Outside the Quota System ${ }^{18}$

Under the quota system the Italian government fixes the number of work permits that may be issued for a given year. This is true for two categories of workers: (1) Autonomous Workers who include professionals working independently or those setting up businesses. Any number exceeding the quota is rejected and (2) Subordinate Workers who include anyone employed by an Italy based company for a fixed term contract or open term contract or seasonal employment.

Although bound by quota, certain selected professional categories are allowed work permits outside the quotas discussed above. These include highly qualified managers, university professors, foreign workers assigned to an Italian company to carry out specific services in the Italian territory on the basis of a services agreement, artists, newspersons, etc.

Italian Business visas are available for individuals as self-employed professionals, merchants, artisans, partners and consultants to Italian firms. ${ }^{19}$ However the business and work visa categories often tend to have intersections. In addition to this, Italy is also covered under the Schengen Agreement as already outlined for Germany, France and the Netherlands.

Appendix A at the end of the paper contains a short description of EU immigration regulations for a few other EU countries for both intra corporate transfers in MNCs and employment of foreign nationals in EU member country firms.

\subsubsection{The Schengen Treaty}

The Schengen treaty initially signed by seven countries in June, 1985 currently includes twenty five countries. Ireland and the UK are the only two countries which are a part of the EU and not a part of Schengen. The Schengen Visa allows individuals to travel across Schengen Countries for a period of 90 days during a six month period. Visas are issued for specific purposes under the categories outlined in Table 8. An applicant for the Schengen Visa needs to apply to the country where s/he travels to first or the country where s/he stays for the maximum duration.

\footnotetext{
18 See Italian Work Permit Process, http://www.mpimmigration.com/index.php?option=com_content\&view=article\&id=48\&Itemid=27 (accessed $25^{\text {th }}$ September, 2011)

${ }^{19}$ See http://www.esteri.it/visti/home_eng.asp (accessed $25^{\text {th }}$ September, 2011)
} 
Table 8. Schengen Visa Description

\begin{tabular}{|l|l|}
\hline Visa Type & Description \\
\hline A (airport transit visa) & Allows transit through Schengen Airport without entry into the territory \\
\hline B (transit visa) & $\begin{array}{l}\text { Allows transit (not more than 5 days) through Schengen Countries by car, } \\
\text { coach or travelling through different airports on way to a non-Schengen } \\
\text { country }\end{array}$ \\
\hline C (short stay visa) & $\begin{array}{l}\text { Allows visit to Schengen territory for purposes of tourism , family or } \\
\text { business visits for 90 days in a given 180 day period }\end{array}$ \\
\hline C (circulation visa) & $\begin{array}{l}\text { Allows short stay (valid at least a year) for business visits with invitation } \\
\text { letter from Schengen country, aircrew members or people with special } \\
\text { interest in the Schengen territory }\end{array}$ \\
\hline D (Long stay visa) & $\begin{array}{l}\text { Allows stay for periods of more than 3 months especially for study, work or } \\
\text { retirement }\end{array}$ \\
\hline
\end{tabular}

Source: Compiled by the authors with inputs from http://www.immihelp.com/visas/schengenvisa/ (accessed $1^{\text {st }}$ November, 2011)

The Schengen Visa requirements are also divided between the countries of the world with a few countries receiving preference over the rest in terms of formalities required to be fulfilled as shown in the world map below:

Figure 3. Schengen Visa Requirements

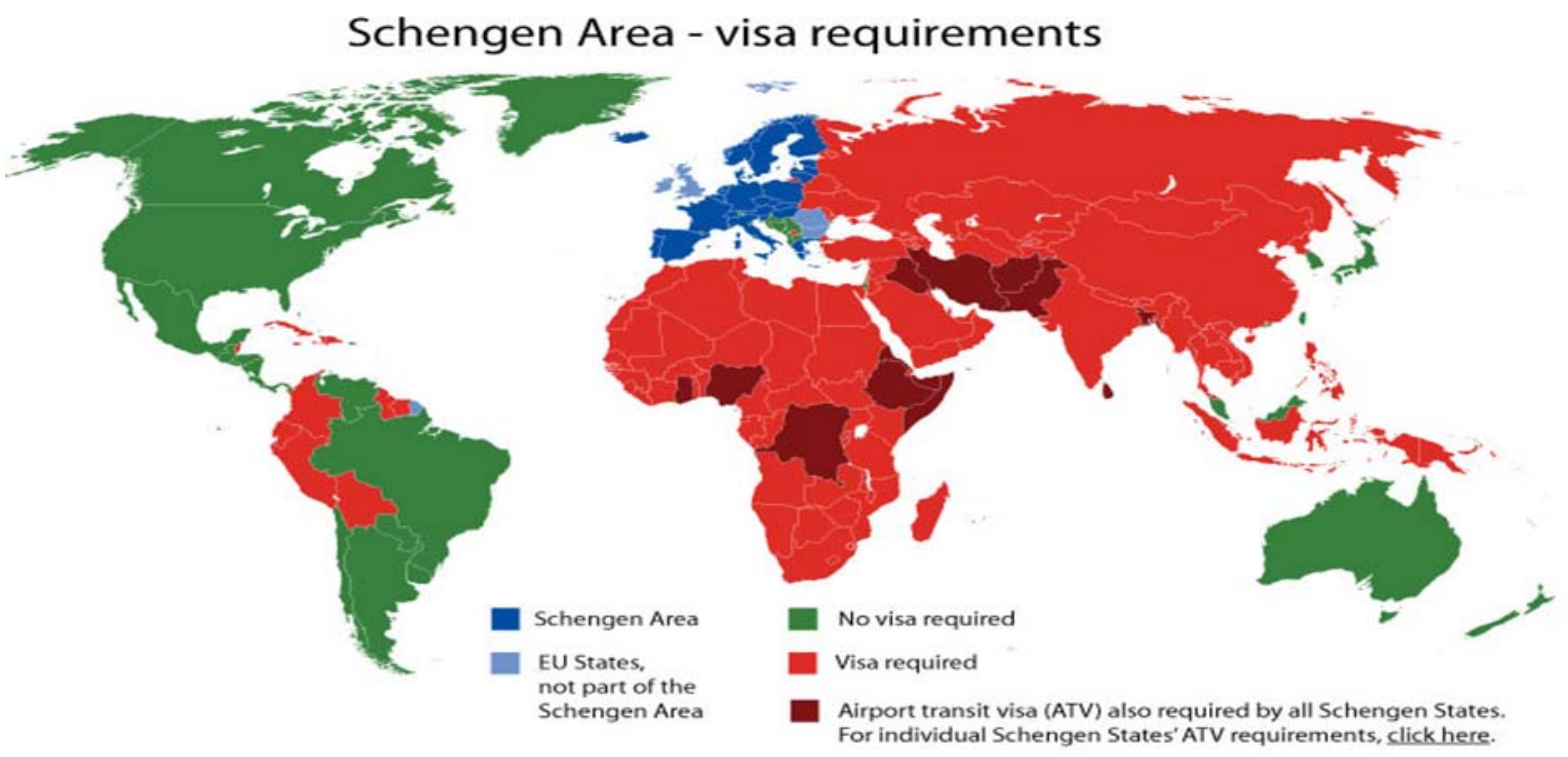

Source: Reproduced from European Commission Home Affairs webpage, http://ec.europa.eu/homeaffairs/policies/borders/borders_visa_en.htm (accessed 1st November, 2011)

As observed from the map above, India is listed in the zone whose residents compulsorily require a visa to travel to the Schengen territory. Schengen rules suggest that applicants are required to apply to the first country of visit for a Schengen visa. However, this is true for short term stay in the Schengen territory (i.e. three months). For longer term stays, the country-specific visa formalities need to be followed. 


\subsubsection{High Skilled Workers Immigration: The EU Blue Card proposition}

Most European countries are currently plagued by a common problem, which is shortage of skilled professionals in various fields. This problem is slated to increase in future as many EU countries are burdened with an ageing population. Some steps have been envisaged for tackling this problem. There are country-specific initiatives such as the German Immigration Act, 2005 to encourage immigration of skilled professionals, as noted earlier. The professions mainly in demand are: professors, scientists, engineers and high technology professionals. Similar initiatives have been undertaken in other EU countries such as Belgium and the UK. This subsection analyses the sectors which have seen higher proportions of FDI inflows and the projected employment gaps in the EU over the long run.

In the recent past the tertiary sector of most EU countries has received the largest share of foreign investment. The table below shows the FDI inflows for selected EU economies from 2007-2010.

Table 9. FDI inflows (flow) in selected EU economies

\begin{tabular}{|c|c|c|c|c|c|}
\hline Country & Sector & 2010 & 2009 & 2008 & 2007 \\
\hline \multirow{3}{*}{ France } & Primary & -648 & 262.9 & 988.8 & 183.4 \\
\hline & Secondary & $5,911.70$ & $1,324.10$ & $19,326.90$ & $6,973.40$ \\
\hline & Tertiary & $-4,574.60$ & $14,435.30$ & $4,356.40$ & $41,042.20$ \\
\hline \multirow{3}{*}{ Germany } & Primary & 176.3 & -57 & $2,217.70$ & 765.1 \\
\hline & Secondary & $17,619.90$ & $10,496.50$ & $-5,608.80$ & $7,553.70$ \\
\hline & Tertiary & $26,415.30$ & $30,301.80$ & $22,410.40$ & $74,110.60$ \\
\hline \multirow{3}{*}{ UK } & Primary & & $-6,222.30$ & $1,080.90$ & 1,738.80 \\
\hline & Secondary & & $8,216.30$ & $34,309.10$ & $23,642.80$ \\
\hline & Tertiary & & $64,806.80$ & $49,848.70$ & $1,61,003.40$ \\
\hline \multirow{3}{*}{ Italy } & Primary & & $6,913.80$ & $7,748.90$ & $4,512.50$ \\
\hline & Secondary & & $4,363.00$ & $4,262.60$ & $6,750.30$ \\
\hline & Tertiary & & $16,856.70$ & $16,779.60$ & $21,460.70$ \\
\hline \multirow{3}{*}{ Poland } & Primary & & 15.8 & 159.9 & 194.9 \\
\hline & Secondary & & $4,749.60$ & $2,282.10$ & $6,839.00$ \\
\hline & Tertiary & & $8,398.50$ & $12,427.60$ & $15,259.30$ \\
\hline
\end{tabular}

Source: Compiled by the authors using statistics from International Trade Centre Investment Map http://www.investmentmap.org/ (accessed $15^{\text {th }}$ April, 2012)

The table reflects that the tertiary sector has by and large attracted a higher proportion of FDI inflows for most of the EU countries consistently. One also finds that investments in the financial and Business Activities segments together make up around 40-90\% of total FDI inflows of the tertiary sector, for most of these countries. 
Table 10. FDI inflows (flow) in finance and Business Activities for selected EU economies

\begin{tabular}{|l|l|r|r|r|r|}
\hline \multicolumn{1}{|c|}{ Country } & \multicolumn{1}{|c|}{ Sector } & \multicolumn{1}{c|}{$\mathbf{2 0 1 0}$} & \multicolumn{1}{c|}{$\mathbf{2 0 0 9}$} & \multicolumn{1}{c|}{$\mathbf{2 0 0 8}$} & \multicolumn{1}{c|}{$\mathbf{2 0 0 7}$} \\
\hline \multirow{2}{*}{ Italy } & Finance & & $8,538.20$ & $8,106.30$ & \multicolumn{1}{c|}{$7,694.60$} \\
\cline { 2 - 6 } & Business Activities & & & & \\
\hline \multirow{2}{*}{ Germany } & Finance & $13,124.80$ & $4,948.50$ & $-9,030.70$ & $25,358.70$ \\
\cline { 2 - 6 } & Business Activities & $13,405.80$ & $25,756.60$ & $23,444.50$ & $41,584.20$ \\
\hline \multirow{2}{*}{ France } & Finance & 585.7 & $19,000.00$ & $3,613.70$ & $12,276.90$ \\
\cline { 2 - 6 } & Business Activities & $9,575.90$ & $7,172.50$ & $9,681.00$ & $21,779.60$ \\
\hline \multirow{2}{*}{ Portugal } & Finance & & $3,219.10$ & $2,216.40$ & $1,494.00$ \\
\cline { 2 - 6 } & Business Activities & $1,220.10$ & 269 & $2,085.90$ & $2,091.10$ \\
\hline \multirow{2}{*}{ UK } & Finance & & $33,662.50$ & $10,333.40$ & $82,631.70$ \\
\cline { 2 - 6 } & Business Activities & & $3,477.80$ & $9,200.90$ & $7,983.60$ \\
\hline \multirow{2}{*}{ Spain } & Finance & $1,826.10$ & -599.4 & $-1,237.80$ & $6,161.70$ \\
\cline { 2 - 6 } & Business Activities & $3,173.90$ & $2,432.50$ & $7,439.90$ & $15,073.10$ \\
\hline \multirow{2}{*}{ Sweden } & Finance & 51.4 & 508.7 & $8,029.90$ & $4,486.60$ \\
\cline { 2 - 6 } & Business Activities & -693.1 & 870 & $3,712.80$ & $5,354.20$ \\
\hline \multirow{2}{*}{ Poland } & Finance & & $2,243.80$ & $4,431.00$ & $3,576.20$ \\
\cline { 2 - 6 } & Business Activities & & $2,799.80$ & $3,915.40$ & $5,972.50$ \\
\hline
\end{tabular}

Source: Compiled by the authors using statistics from International Trade Centre, Investment Map http://www.investmentmap.org/ (accessed $15^{\text {th }}$ April, 2012)

Reports on employment projections in the EU confirm greater job vacancies in the finance and business activities segments in the near and long term. These are also the sectors where the EU has most outward investments, indicating a linkage between sectoral investments, growth and labour requirements. The figure below shows that business and other services have seen greatest growth, confirming this link between investment, growth, and labour market needs, and thus by inference, also immigration requirements across sectors. 
Figure 4. Employment Trends by Broad Sector Shares in EU-25+Norway and Switzerland

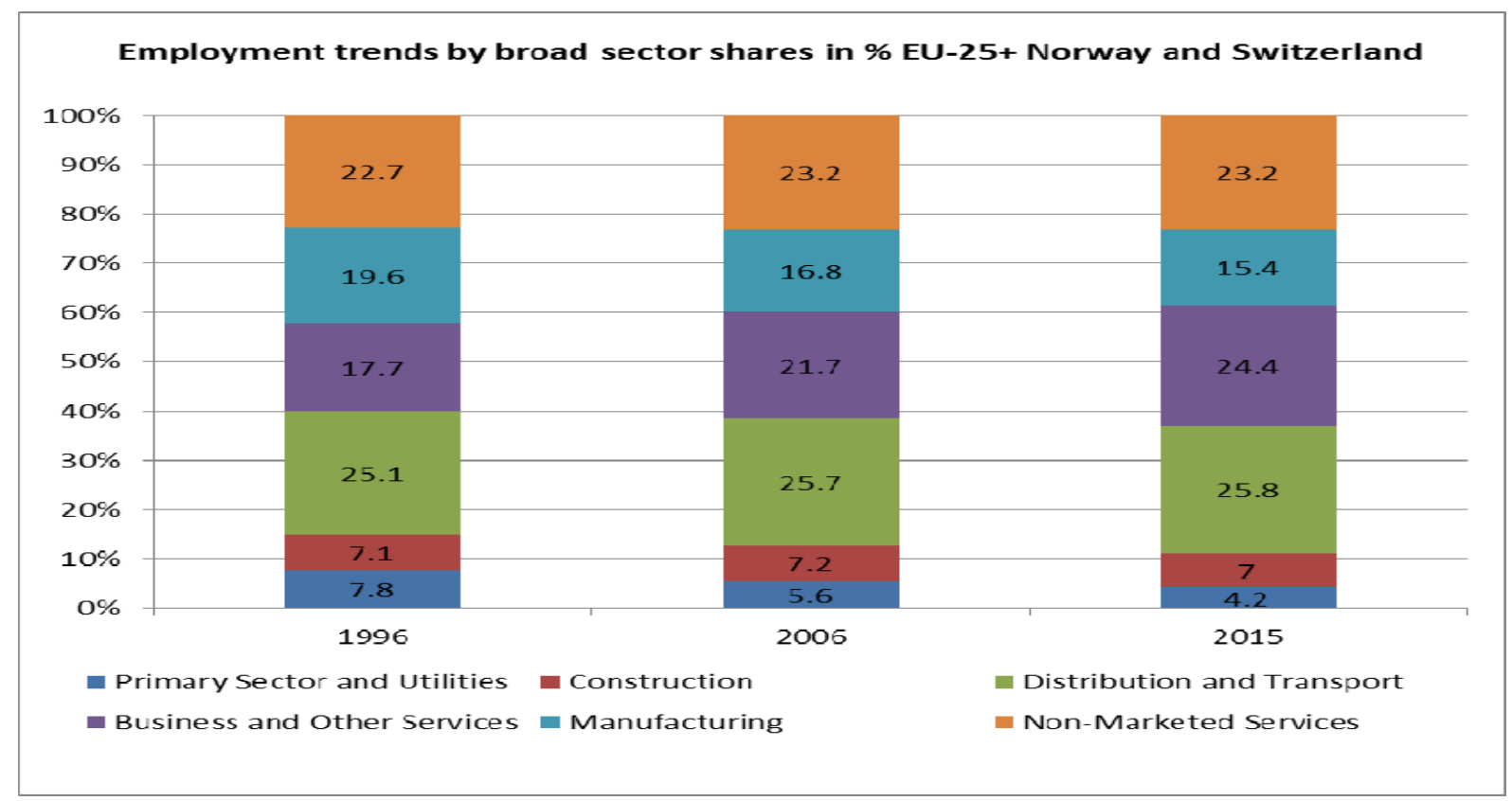

Source: Cedefop (2008) Future Skill Needs in Europe Medium Term Forecast, Luxembourg. Figure 3, p. 42. Note: Figures are as per IER (Warwick) Estimates based on Cambridge Econometrics E3ME model ${ }^{20}$

The EU is, however, predicted to experience significant decreases in its working age population. The figure below shows the working age population forecasts for a few EU countries.

Figure 5. Working Population Projections

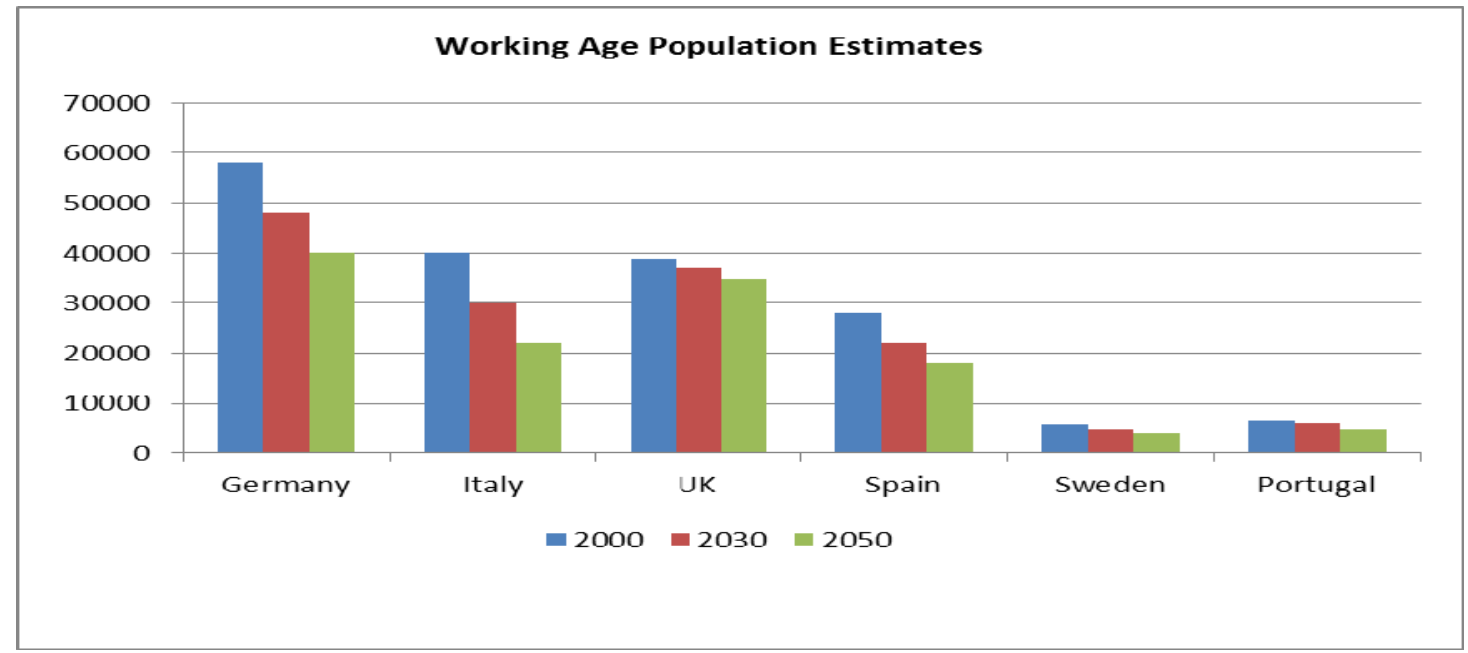

Source: World Population Prospects 1950-2050, United Nations The 2000 Revision (Feb, 2001), New York

Table 11 shows the estimated employment gap by 2050 and the required employment rate required to fill the vacancies against a current employment rate of around $63 \%$. Table 12 shows the number of skilled workers coming to select EU countries in recent years, mostly on short-term visas.

${ }^{20}$ E3 refers to Energy-Environment-Economy. E3ME models were first constructed for analyzing long term implications of policies on Energy-Environment-Economy. For more details, see: Pollitt (2009) “The E3ME Front End”, Cambridge Econometrics, Cambridge. 
Table 1. Employment gap in the EU by 2050-four scenarios

\begin{tabular}{|l|c|c|}
\hline \multicolumn{1}{|c|}{ Scenario } & Employment gap (in thousands) & $\begin{array}{c}\text { Employment rate needed to } \\
\text { close gap }\end{array}$ \\
\hline Ageing Effect only & 30,485 & $76 \%$ \\
\hline Baseline Scenario & 30,216 & $76 \%$ \\
\hline No Migration Scenario & 20,904 & $78 \%$ \\
\hline Low growth & 25,915 & $75 \%$ \\
\hline High growth & 36,972 & $76 \%$ \\
\hline
\end{tabular}

Source: Cedefop (2009), “Skills for Europe’s Future: anticipating occupational skill needs”, Table 3.2, p.32, http://www.cedefop.europa.eu/EN/Files/5194_en.pdf (accessed 10 $0^{\text {th }}$ June 2012)

Table12. High skilled workers entry from non-EU nations

\begin{tabular}{|l|r|r|r|r|r|r|}
\hline \multicolumn{1}{|c|}{ Country } & \multicolumn{1}{c|}{$\mathbf{2 0 0 4}$} & \multicolumn{1}{c|}{$\mathbf{2 0 0 5}$} & \multicolumn{1}{c|}{$\mathbf{2 0 0 6}$} & \multicolumn{1}{c|}{$\mathbf{2 0 0 7}$} & \multicolumn{1}{c|}{$\mathbf{2 0 0 8}$} & \multicolumn{1}{c|}{$\mathbf{2 0 0 9}$} \\
\hline Poland & 5083 & 4583 & 4046 & 4424 & 4920 & 5697 \\
\hline UK & 69000 & 52000 & 58000 & 52000 & 50000 & 36000 \\
\hline Spain & & 8899 & 3462 & 4637 & 9407 & 6568 \\
\hline France & 917 & 981 & 1111 & 1254 & 3124 & 3953 \\
\hline Germany & & & & 151 & 221 & 311 \\
\hline
\end{tabular}

Source: European Migration Network (2011), “Satisfying Labour Demand through Migration”, European Commission, Table 8, p.77, http://ec.europa.eu/home-

affairs/policies/immigration/docs/Satisfying_Labour_Demand_Through_Migration_FINAL_20110708.pdf (accessed 15th July, 2012)

These tables and charts clearly highlight that skill deficits in the EU are a long-term problem and that short-term work permits will not be enough to solve the problem. However, issuance of long term permits remains a sensitive issue in the EU, notwithstanding the need for such workers. ${ }^{21}$

In recognition of the shortage of high skilled workers the EU Blue card scheme had been proposed and agreed upon to have common rules of immigration for highly skilled workers from outside the EU. ${ }^{22}$ Countries like Denmark, UK and Ireland are, however, outside the purview of this scheme. It has been left to the countries to choose if they want to participate in the Blue Card or not. The purpose of the scheme is to: ${ }^{23}$

a. facilitate the admission of these persons by harmonising entry and residence conditions throughout the EU;

b. simplify admission procedures and

c. improve the legal status of those already in the EU

\footnotetext{
${ }^{21}$ The authors avoid a more elaborate discussion of this here as a separate paper is being prepared on this.

${ }^{22}$ See European Union, “EU Blue Card”, http://www.apply.eu/BlueCard/ (accessed $2^{\text {nd }}$ August, 2012)

${ }^{23}$ See European Union (2009) “Entry and residence of Highly qualified workers (EU Blue Card)”, and EC Directive (May 2009), 2009/50/EC
} 
The Blue Card scheme allows highly skilled workers from third countries to work in the EU for an initial period of four years if they have a college diploma or have completed five years of occupational training. The applicant for an EU Blue Card must have:

a. a work contract or binding job offer with a salary of at least 1.5 times the average gross annual salary paid in the Member State concerned (Member States may lower the salary threshold to 1.2 for certain professions where there is a particular need for third-country workers);

b. a valid travel document and a valid residence permit or a national long-term visa;

c. proof of sickness insurance;

d. for regulated professions, documents establishing that s/he meets the legal requirements, and for unregulated professions, the documents establishing the relevant higher professional qualifications.

The Blue Card thus issued could be renewed or converted into permanent residence after five years. Blue Card holders are able to avail the same social and labour rights as the original residents of the country, in addition to the right to family reunification.

The scheme, however, is still to be implemented by several EU countries that need to approve blue cards for skilled immigrants along with their families. It has also faced opposition due to increased unemployment in the EU.

In sum, based on the immigration regulations outlined in this section it can be inferred that the norms vary substantially across EU member countries (In fact one could design a labour mobility index just as has been done for investment openness ${ }^{24}$.). Individual countries also vary in terms of the category of visas commissioned. The Schengen Visa facilitates movement of tourists and professionals visiting multiple EU member countries that are signatories to the Schengen Treaty. Countries like the UK, are however, not a part of this treaty. Finally, the dearth of skilled professionals in most EU countries has led to special provisions for skilled professionals' immigration to various EU countries through more conducive visa regulations. The EU Blue Card Scheme has been envisaged for easier immigration of skilled professionals into the member countries of the EU Blue Card. Countries like the UK and Ireland have chosen not to be a part of this treaty.

The following section highlights the findings from the depth interviews conducted by the authors. It outlines the characteristics of Indians travelling to the EU and the associated constraints they face.

\section{Labour Mobility from India to the $\mathrm{EU}^{25}$}

\subsection{Profiles of Indian nationals visiting the EU}

The need for Indian nationals to travel to the EU may occur due to two types of Investment relations:

1. As employees of EU based MNCs with operations in India

Employees of MNCs may need to travel to the EU for two primary reasons:

i. To upgrade skills

ii. Attend business meetings/conferences

iii. To know the job requirements for offshored business processes

(Contd.)

http://europa.eu/legislation_summaries/internal_market/living_and_working_in_the_internal_market/14573_en.htm (accessed $15^{\text {th }}$ November, 2011)

${ }^{24}$ The design of this index is not attempted in this paper but is worth taking up in future research on labour mobility.

${ }^{25}$ This section of the paper draws on from a previous study by Chanda (2008) 
The first is mainly for employees in the lower or middle levels of corporate hierarchy who travel for short durations to upgrade skills and employ the same in India on return. The second includes travel by senior corporate managers who need to attend business meetings or workshops for short periods of time. Finally, the third- a recent development after the onset of offshoring, includes relatively junior employees mainly skilled software engineers or analysts who need to travel to the EU to understand the job requirements for the EU market. Since early 2000, many European MNCs have set up teams in India where employees work and on occasion travel to the EU for short periods of about three months to understand the software and for the purpose of knowledge transfer.

2. As employees of Indian companies with EU engagements

With the rise of offshore outsourcing, various Indian companies, with or without business presence in the EU, are serving client companies based in Europe. Employees of such companies are required to travel to the EU for reasons similar to those discussed earlier for offshore employees of MNCs. However, the issues faced by the Indian companies with regard to short-term transfer of their employees to the EU are quite different from those faced by MNCs with operations in India and which need to send their employees in India to locations in the EU.

The following section discusses some features of the immigration policies of EU countries and their bearing on investment-related mobility between India and the EU, based on interviews conducted by the authors.

\subsection{Features and Implications of immigration to the EU}

Most respondents agreed that although immigration guidelines are unambiguous for the EU, the applicants suffer due to long timelines, cumbersome processes and procedural requirements. Some countries do not have a long term multiple entry visa system. There are tedious legalisation and attestation requirements. Large variations exist across countries even in terms of visa renewals and allowing dependants to migrate. A detailed analysis is provided below to highlight the key features.

\subsubsection{Work and Business Visa}

The key features of work and business visas are listed below:

- Work/employment Visas have different procedures for different countries and the time required for approving a work visa may vary from a few weeks in the case of the UK to around 1-2 months for some EU countries

- A business visa is applicable to individuals who wish to visit the particular EU country to start a new business, expand an existing business or attend business meetings.

- Countries like Italy and France have "Self-employed professionals" and "Skills and Talent permit" which allow both employers and employees to immigrate, bypassing the work visa formalities.

- Normally work visas are issued for three months but the procedure involves obtaining permissions from the labour ministry. For most EU countries, a prior advertisement for similar skill sets in the country concerned is a necessity and only in the case of non-availability of the same is a foreign citizen allowed to immigrate

- Work Visas also imply taxes and social security payments by the immigrant worker. The business visas are exempt from taxes and social security payments as the individual is not supposed to be employed

Respondents complained about thin lines of difference between work and business permits. Ambiguity in terms of requirements for most countries and equivocation in the definition of visas have 
led to work and business individuals travelling to the EU on business and work visas, respectively, in several cases.

According to the respondents, there have been multiple misunderstandings about the visa categories on the part of both EU and Indian companies. Employees travelling on business visa end up doing work which would qualify for a work permit. There have been legal problems due to this in the past with Indian nationals facing arrest because of travelling on an incorrect visa category. ${ }^{26}$ Subsequently, some organizations have put in place strong policies and for any kind of work being done on-site, a work permit is obtained.

There are also problems with documentation requirements. While applying for a work permit the applicant needs to show the birth certificate and other original documents. The authenticity of some Indian documents is at times questioned by the consulates. MNCs, especially from the EU put in an effort to make this process smooth. A few MNCs identify potential resources who are likely to travel overseas in the near future and facilitate the organisation of documents in advance to enable them to apply on short notice for a work permit. For the legalization process some companies hire an external agency for verification of documents and get these notarized. In the wake of offshoring, some companies followed this procedure in 2000-01. There was a significant initial cost for this process, but the investment was made to ensure that the right skill sets could move easily when required. Indian employees of EU MNCs find it easier to travel than those of Indian companies. Traditionally, some

EU MNCs due to their established reputation can manage the visa system more efficiently, thereby reducing the total turnaround time for obtaining a visa.

\subsubsection{Transparency}

Most respondents specified that although the procedures for applying for work permits and business visas are outlined clearly by the EU countries, there is lack of transparency in the decision making process in terms of whether a permit is finally granted or not. There are cases where in spite of all the formalities being met, the visas were denied without any specific reasons. Hence greater streamlining in the decision making process for granting visas in EU countries would help both Indian companies and EU companies who send Indian employees to the EU and in understanding the reasons behind acceptance and rejection of visa applications.

\subsubsection{Investment Presence in the EU and Work Permits}

This relates to Indian companies which have engagements with Europe either as suppliers of intermediate inputs to EU firms from offshore (India) or as players in the EU market or which are present in the EU through joint ventures/partnerships. It was revealed through the interviews that the time taken to establish presence varies across EU member countries from two weeks to several months. Employment terms and conditions vary. In most cases no distinction is made between high and low value investments. The business environment varies across EU members as well.

Respondents from the IT sector indicated that it is easier to enter and operate in the EU market of any country in partnership with a local firm. This helps them understand the market better and to cater to market demands more efficiently. For companies which are not in partnership with local firms, having a branch or a subsidiary in the EU helps them establish an identity. Labour mobility is indeed facilitated by presence in the EU. A company with a branch or subsidiary presence is a source of

\footnotetext{
${ }^{26}$ The case of I-flex where the CEO and some employees of the company were detained in the Netherlands for travelling with business visas when they were working in the country is testimony to the kind of problems that may arise due to the thin lines of difference between the work and business visas. See Indian Express (March 30, 2003)
} 
employment for EU workers. Since these companies play a role in local employment, they find it easier to obtain short term work permits for their Indian employees when such a requirement arises.

Due to the increased incidence of offshoring, a significant number of Indian IT professionals need to travel to the EU to understand the requirements of their clients and deliver accordingly. Depending on the laws of the country, the company shifts persons from India to the overseas site. Wage laws, contracting and hiring laws are complex in some countries, such as in the Netherlands. Companies also hire locally and in certain cases have to abide by local employment regulations to set up commercial presence in the first case. Labour market tests impose additional costs of hiring in certain cases.

However, one of the main problems faced by the Indian companies which have investment presence across multiple EU countries is that each EU country follows its independent immigration policy. ${ }^{27}$ Additionally, companies face other problems related to overtime payments which they have to abide by, given strict labour laws. Most companies do not have to pay overtime to employees in India. Conditions on maximum working hours, leave requirements and firing and downsizing costs are other factors that increase costs of operations in the EU. Respondents suggested that it would be beneficial for Indian companies with presence across different EU countries if the formalities were streamlined and standardised. ${ }^{28}$

\subsubsection{Immigration of Dependants}

The interviews revealed that EU member countries vary widely in terms of allowing dependants of immigrant workers to reunite as a family. The UK and Germany are the most liberal in this regard. The variations in ability to accept dependants in turn leads to differences across the EU countries in their ability to attract skilled professionals.

\subsubsection{Schengen Visa}

It was learnt from the interviews that most Indian nationals travelling to the Schengen territory in the EU for work purposes avail of the type $\mathrm{C}$ short stay visa listed in Table 4 above. The Schengen Visa is one of the most useful options available to Indian nationals travelling to the EU who need to travel to multiple countries for work purposes. Apart from the benefits of allowing visa holders to work across the Schengen territory, the respondents noted that the visa approvals take only 2-10 days. The simplified means of obtaining quicker approvals for work across the territory are a major benefit that Indian nationals travelling to the EU are able to avail.

According to some respondents, the benefits of the Schengen treaty could be realised to a greater extent if non-members of the Schengen treaty especially the UK and Ireland would consider signing it. Broadening the scope of the Schengen to include countries like the UK which have had long term investment ties with India would undoubtedly facilitate labour mobility and foster greater links between India and the UK.

\subsubsection{Totalisation}

Appendix A of this paper provides a brief note on totalisation and the purpose and progress of totalisation agreements between India and some EU countries.

\footnotetext{
${ }^{27}$ See Appendix B in Chanda, R. (2008), “Trade in IT and IT-enabled services: Issues and Concerns in an India-EU Trade and Investment Agreement “, ICRIER, New Delhi

${ }^{28}$ Alternatively as Chanda (2008) specifies, if EU member countries would recognise similar visa procedural formalities, offer greater flexibility in case of business visas across member countries, create finer categories of visas between work and business, it would facilitate labour mobility from India to the EU.
} 
Most respondents believe that India has had mixed success in its bilateral agreements with various nations. There is also no EU wide policy to facilitate such agreements. Most EU member countries have their own policies regarding social security which makes it difficult to sign one common treaty and for Brussels to take a uniform approach on this issue. Interviewees pointed out that it could, however, be beneficial for India and also for respective EU countries to bilaterally negotiate such totalisation agreements by maintaining a model agreement (like the one with Belgium) with those EU countries that are of strategic importance to India in terms of labour mobility.

\subsubsection{Mobility of Skilled Professionals}

Most EU countries facing a skill deficit are making efforts to facilitate labour mobility especially of highly skilled personnel like IT workers. The skill deficit and the longer term implications of the same can be appreciated if one observes the trends investment and employment expansion potential of the European Union presented in section 4.1.3 earlier.

The interviewees suggested that the shortage of skills in the EU has been a key driver for facilitating the movement of Indian IT professionals for short and long term work purposes. It was pointed out that these days many UK companies hire Indians not only from the UK but directly from India. However, the scenario varies across EU countries. Countries like Belgium which initially had backlashes against Indian IT companies have managed their problems well and now offer a conducive atmosphere for IT professionals to work. Processing of permits is faster in Belgium. They also allow professionals to bring in their dependents, although the process for the latter may be time consuming. Having an investment presence in Belgium is advantageous for firms. Obtaining work permits for Indian IT workers, however, remains a problem in countries like France and getting long-term work permits is still difficult.

\subsubsection{EU Blue Card}

Most respondents specified that this is undoubtedly one of the most welcome moves for Indian employees seeking to travel to the EU countries. The card would be of greater relevance to employees who need to stay in the EU for longer periods (more than three months). ${ }^{29}$ Family unification problems, which has been cited for some countries would also be solved more easily.

\subsubsection{Labour Mobility and Investment}

Several respondents highlighted the fact that labour mobility restrictions in certain countries are one of the main factors which discourage investment and economic growth in certain EU countries. For instance, in countries such as Italy where there is a quota for work permits issued every year, shortterm visas and residence permits are not easily available for those doing business. This adversely affects foreign investments in Italy, including by Indian companies as businesses face restrictions in obtaining work permits and sending Indian nationals to Italy for short or long-term. The poor growth performance and inability to attract foreign investments by countries such as Italy was attributed by some respondents to their restrictive immigration policies, thus again highlighting the connection between investment and associated labour flows.

\footnotetext{
${ }^{29}$ In the past, workers posted in any EU country would not be allowed to work in another EU country without a separate work permit from the latter country. However with the implementation of the Blue Card this extra work permit would not be necessary.
} 


\section{Immigration to India}

\subsection{Indian Visa}

The Indian visa categories most relevant for EU professionals in the context of this paper are:

1. Business and

2. Work/Employment.

The business visa can be issued for a period of three months to five years. It requires amongst other formal documents, a letter of invitation from an Indian sponsoring company. Anyone visiting India using this visa is not allowed to take up employment ${ }^{30}$. The Indian employment visa allows the holder to live and work in India. The employment visa can be extended in instalments of one year and requires a range of documents to be submitted. Obtaining a work permit from India for relatively longer periods is easier and immediate family members are allowed to join the professional in India. However, in case the dependants need to work in India, a separate work permit is necessary. ${ }^{31}$

\subsection{Profile of EU professionals Visiting India}

EU professionals travelling to India can be segmented into the following categories based on the purpose of visit:

1. Professionals travelling for a short time to attend business meetings or conferences,

2. Professionals at senior levels travelling to ensure smooth setting up and functioning of business and

3. Professionals travelling to train Indian workers in MNCs.

\subsection{Features of the Indian Immigration System}

The issues faced by EU nationals visiting India are uniform across different categories of professionals. Primarily, Indian visa regulations are seen to be subjective in nature and lacking in streamlined processes. The processing time for visa requests is dependent on the time of the year, nationality of the applicant and the visa class. However, normally it takes around ten days to process an application. Most respondents complained about the lack of transparency and the subjectivity involved in granting Indian visas. There are disparities in terms of formalities to be fulfilled not only across consulates in different EU countries but also across consulates in the same EU country. It was clear that visa rejections are avoided in cases of intra company transfers from one office of an MNC to another in India. Delays often result due to mistakes on the part of Indian embassy officials on account of incorrect information given by them for visa requirements. The subjectivity and discretion involved in the issuance of a work permit creates problems even after all the formalities are completed. All EU nationals finally entering India for work are required to report at the local police station to fulfil further formalities. Thus, lack of timely processing, uncertainties, discretionary handling and cumbersome processes were among the most cited problems with respect to entering India.

\footnotetext{
30 See Worldwide Visa Bureau, “India Visa”, http://www.visabureau.com/worldwide/india-visa.aspx (accessed $22^{\text {nd }}$ November, 2011)

${ }^{31}$ See Global Visas, “Indian Work Permit” http://www.globalvisas.com/india_visas/indian_work_permit.html (accessed $22^{\text {nd }}$ November, 2011)
} 


\section{Conclusion}

This paper has discussed the links between foreign investment and labour mobility in the context of India and the EU. Secondary evidence suggests that there has been significant liberalization of investment regulations by India and by most EU member countries. However, immigration statistics and examination of visa regulations suggest that there are different degrees of restrictiveness in investment and immigration regulations in different EU countries.

The in-depth interviews conducted by the authors indicate ambiguities in differentiating between work and business visas in most EU countries and problems related to transparency in granting visa requests and with the immigration of dependants. Issues related to totalisation are another cause of concern. These are currently being dealt with through bilateral social security agreements between India and respective EU members.

The Schengen Agreement has proved to be an useful development especially for Indian IT companies who require to move employees from one European country to another serving clients across various countries. However, the Schengen Visa may be of greater use if other EU member countries which are currently not included in the treaty come under its umbrella.

The dearth of highly skilled professionals in the EU has led countries to relax immigration regulations for skilled professionals recently. In addition to this, the EU Blue Card scheme has been proposed for hassle free immigration of skilled professionals from outside the EU. This is of benefit to most Indian skilled professionals. However, the introduction of the scheme has been delayed due to protests in some cases related to fears of greater unemployment in the EU member countries. Estimates of long term shortages of high skilled employees in the Europe show how important it is for the EU manage longer term immigration of skilled professionals.

For EU professionals travelling to India, Indian visa formalities tend to be non-transparent and ambiguous. However, Indian work permits are available for longer durations and dependant immigration is also easier. Most respondents complained about a significant level of subjectivity involved in the visa procedures.

In sum, while India and the EU have both liberalized their investment regulations, further steps need to be taken by both sides to facilitate skilled immigration and business related flows. In some EU countries, strict immigration restrictions by way of quotas have also been found to inhibit foreign investment flows as it is difficult to temporarily get skilled employees to carry out business activities. Although the Schengen agreement and the EU Blue Card scheme are welcome steps towards improving labour mobility that is associated with investment, they are not yet fully implemented in all EU countries. On the Indian side, the process of obtaining an Indian work or business visa needs to be made more transparent and less subjective. 


\section{Appendix A}

\section{A.1 Immigration regulations of selected EU countries}

The extent of variation across EU member countries can be analysed in terms of regulations for (1) International intra corporate transferees of multinational corporations and (2) Direct recruitment of foreign skilled nationals for employment. Table below outlines the duration of stay by foreign nationals laid out by selected EU countries for the case of intra corporate transferees. Similarly, 
Table outlines the different methods, namely: Drawing up occupational lists, Employer Needs analysis and Quota systems that form the main pillars of approaches by EU member countries in managing international labour inflows. Differences across countries in both these segments are easily discernible.

Table A.1. Duration of stay for Intra-Corporate transferees in selected EU countries

\begin{tabular}{|c|c|c|}
\hline Country & Duration & Comments \\
\hline France & 3-9 months & $\begin{array}{l}\text { Exception in the case of Bulgaria and Romanian nationals in } \\
\text { 2008, whose length of stay was between } 1.5 \text { and } 2 \text { months }\end{array}$ \\
\hline Germany & Maximum 3 years & \\
\hline Ireland & $\begin{array}{l}\text { From }<1 \text { year to } \\
2 \text { years and may } \\
\text { be extended to } 5 \\
\text { years in totality }\end{array}$ & $\begin{array}{l}\text { In Ireland, the duration of stay for ICTs depends on the reason } \\
\text { for transfer. Evidence reveals that this may extend from less } \\
\text { than two years for the construction sector to less than one year } \\
\text { for the IT sector. }\end{array}$ \\
\hline Poland & $\begin{array}{l}\text { Greater than } 30 \\
\text { days }\end{array}$ & $\begin{array}{l}\text { Work Permit for third country nationals working for a foreign } \\
\text { employer and posted to Poland }\end{array}$ \\
\hline Spain & $\begin{array}{l}\text { One year } \\
\text { maximum }\end{array}$ & Possibility of extension of another year. \\
\hline
\end{tabular}

Source: Reproduced from EMN (2011), Table 2, p.40 
Table A.2. Approaches used by Selected EU countries to manage labour Immigration

\begin{tabular}{|c|c|c|c|}
\hline Country & Occupation Lists $^{\mathrm{a} /}$ & $\begin{array}{c}\text { Employer needs } \\
\text { Analysis }^{\mathbf{b} /}\end{array}$ & Quota $^{\text {c/ }}$ \\
\hline Belgium & $*$ & $*$ & \\
\hline Czech Republic & & $*$ & \\
\hline France & $*$ & & \\
\hline Germany & $*$ & $*$ & \\
\hline Ireland & $*$ & $*$ & \\
\hline Italy & & $*$ & $*$ \\
\hline Netherlands & & $*$ & \\
\hline Poland & $*$ & $*$ & \\
\hline Portugal & & & $*$ \\
\hline Spain & $*$ & $*$ & \\
\hline Sweden & & $*$ & \\
\hline United Kingdom & * & & $*$ \\
\hline
\end{tabular}

Source: Reproduced from EMN (2011), Table 3, p. 44

Notes:

a/ Occupational Lists: Starred countries draw up lists of professions where domestic labour shortages exist. The basis or format of formulating these lists may however vary across countries.

b/ Employer needs analysis: Starred countries require employers to directly analyse their labour needs where migrant labour may be required.

c/ Quota: Starred countries adhere to quotas or limits on migrant workers who can enter in a given year. 


\section{A.2 Facts on Totalisation}

Indian citizens travelling to the EU with work visas need to compulsorily subscribe to the social security system. The registration process may take a few months. The incidence of taxes for different countries in the EU varies considerably. ${ }^{32}$ In countries like France this amounts to $22.5 \%$ of the total monthly salary. Some of the benefits covered under social security include: pensions at old age, expenses on sickness and maternity, expenses due to occupational work and illness, invalidity allowance, etc.

One is able to avail of the benefits of the contributions only after around forty years of service. If an individual works till the age of sixty but has worked for less than twenty years in the country concerned, his pension would not be at par with others who have worked for more years. This has been a source of problem for individuals travelling on short term work visas from India who return to India after the assignments and cannot claim the benefits of the social security that these countries provide.

The Indian government has thus started the process of signing totalisation agreements with various countries to manage the social security payments made to ensure adequate benefits for short term Indian workers in the country concerned. At present, India has totalisation agreements with eleven countries which include: Belgium, France, Germany, Switzerland, the Netherlands, Hungary, the Czech Republic, Denmark and Luxembourg, Republic of Korea, Norway. ${ }^{33}$ The Government of India is in talks with other countries in the EU like Bulgaria, Austria, Cyprus, Finland, Greece and Italy to sign similar agreements with them. The aim of these agreements is to provide for:

1. Exemption from social security contribution in case of short-term contracts

2. Exportability of pension in case of relocation to the home country or any third country

3. Totalisation of the contribution periods,

The agreements are neither equally successful nor are they on equal terms as outlined next:

- Belgium

In this case, one can keep paying for social security in India or can choose to pay in Belgium. One does not have to pay extra taxes and if one is not going to avail of benefits then one does not need to pay taxes in Belgium. Only Indian PF contributions can be paid.

- The Netherlands

In the case of The Netherlands, there are two types of retirement schemes: (1) Individuals receive benefits from the company itself as provident fund, or (2) they receive benefits from the government as pensions. The totalisation agreement with The Netherlands (signed in 2010) allows Indian citizens who work on temporary work permit in the former enjoy the pension even if they return to India. Similarly, if a Dutch citizen works in India he/she is not required to pay social security contributions in India and can avail of the retirement benefits if they are in India post retirement. The agreement covers old age pension. Pensions are thus transferable.

\footnotetext{
32 See "Taxes in Europe" database- List of minor taxes (Revenue less than 0.1\% of GDP and NOT in the TEDB), Edition 2011 (http://ec.europa.eu/taxation_customs/resources/documents/taxation/gen_info/info_docs/tax_inventory/list_minor_taxes_ en.pdf) The "Taxes in Europe database" covers the major taxes but the link is inactive at present. The following link gives a broad outline of taxes (http://ec.europa.eu/taxation_customs/taxation/gen_info/info_docs/tax_inventory/index_en.htm) $\quad$ (Accessed: $20^{\text {th }}$ November, 2011)

33 See Ministry of Overseas Indian Affairs, "Bilateral Agreements”, Government of India http://moia.gov.in/services.aspx?id1=81\&idp=81\&mainid=73 (accessed $15^{\text {th }}$ November, 2011)
} 
- Germany

The Social Security Agreement with Germany for posted workers (signed in 2008), has several gaps and has not been as successful according to most respondents. ${ }^{34}$ However, the latest comprehensive agreement on social security in October, 2011 may have addressed most of the gaps in the previous agreement.

- France

The agreement with France has been helpful as well. ${ }^{35}$

34 See Ernst \& Young (2009) and Ministry of Overseas Indian Affairs, Government of India, The Agreement text, http://www.moia.gov.in/pdf/SSAGermanyAgreementENG_final_INDAside.pdf (accessed $13^{\text {th }}$ June, 2012)

${ }^{35}$ See Ministry of Overseas Indian Affairs, Government of India “Agreement on Social Security Between The Government of Republic of India and the The Government of the French Republic"

(http://moia.gov.in/pdf/SSAFranceEng_versionforIndia.pdf) (accessed $20^{\text {th }}$ November, 2011) 


\section{References}

Aitken, B., \& Harrison, A. (1999), "Do Domestic Firms Benefit from Direct Foreign Investment? Evidence from Venezuela”, American Economic Review, 89(3), 605-618

Barba, N., Giorgio, \& Venables, A. (2004), Multinational Enterprises and Foreign Direct Investments: Theory and Evidence, Princeton University Press

Bhagwati, J., \& Hamada, K. (1973), "The Brain Drain, International Integration of Markets for Professionals and Unemployment: A Theoretical Analysis", Journal of Development Economics, 19-42

Borga, M., \& Zeile, W. (2004), "International Fragmentation of Production and Intrafirm Trade of US Multinational Companies”, Bureau Of Economic Analysis Working Paper No. WP2004-02, Washington, DC

Caves, R. (1974), "Multinational Firms, Competition and Productivity in Host Country Markets", Economica, 41, 176-193

CEIC Database, http://www.ceicdata.com/ (accessed 30th September, 2011)

Cedefop (2009), “Skills for Europe’s Future: anticipating occupational skill needs”, Cedefop Panorama Series, Luxembourg

Cedefop (2008), “Future Skill Needs in Europe Medium Term Forecast”, Luxembourg

Chanda, R. (2008), “Trade in IT and IT-Enabled Services: Issues and Concerns in an India-EU Trade and Investment Agreement”, Indian Council For Research on International Economic Relations. New Delhi

Chanda, R. (2011), "Labour Mobility Provisions in RTAs", International Seminar on Selected Outstanding Issues in Migration, ADB Institute. Manila

Clemens, M. (2010), “A Labour Mobility Agenda for Development”, Working Paper 201. Centre for Global Development. Washington, DC

Das, S. (1987), "Externalities and Technology Transfer Through Multinationals Corporations - A Theoretical Analysis”, Journal of International Economics, 22, 171-182

Dunning, J. (1981a), "Explaining the international direct investment position of countries: Toward a dynamic or developmental approach”, Weltwirtschaftliches Archiv, 11, 30-64

Dunning, J. (1981b), International Production and the Multinational Enterprise, London: George Allen \& Unwin

Dunning, J. (1988a), Multinationals, Technology and Competitiveness, London: Unwin Hyman

Dunning, J., \& Cantwell, J. (1990), "The changing role of multinational enterprises in the international creation, transfer and diffusion of technology" in F. Arcangeli, P. A. David and G. Dosi, eds. Technology Diffusion and Economic Growth: International and National Policy Perspectives, Oxford: Oxford University Press

Enrst \& Young (November 2009), “HR and tax alert India- Germany" http://www.ey.be/EYBE/HumCapAl.nsf/c4dede06060fcd87c125757f002e6fa0/519f62a7f4c4615bc 1257689002a70d1/\$FILE/India-Germany\%20-\%20India-

Germany\%20totalization\%20agreement.pdf (accessed 20th November, 2011)

Eur-Lex (May 2009), Council Directive 2009/50/EC On the conditions of entry and residence of third-country nationals for the purposes of highly qualified employment, http://eurlex.europa.eu/LexUriServ/LexUriServ.do?uri=CELEX:32009L0050:EN:NOT (accessed $15^{\text {th }}$ July, 2012) 
Eurofast (2011), “Outbound Indian Investments via Cyprus: The key to the International Market”, Nicosia, Cyprus http://www.eurofast.eu/dev1/phocadownload/articles/ar11_004\%20cyprus_outbound\%20indian\%2 0investments\%20via\%20cyprus\%20jan\%202011.pdf (accessed 20th October, 2011)

Europa, "Entry and residence of Highly qualified workers (EU Blue Card)" http://europa.eu/legislation_summaries/internal_market/living_and_working_in_the_internal_mark et/14573_en.htm (accessed 15th November, 2011)

European Commission, Home Affairs Webpage, http://ec.europa.eu/homeaffairs/policies/borders/borders_visa_en.htm, Brussels (accessed 1st November, 2011)

European Commission, Trade for India page, http://ec.europa.eu/trade/creating-opportunities/bilateralrelations/countries/india/, Brussels (accessed 11th October, 2011)

European Commission (2011) "Taxes in Europe" database- List of minor taxes (Revenue less than $0.1 \%$ of GDP and NOT in the TEDB), Edition 2011. Taxation and Customs Union, European Commission, Brussels

http://ec.europa.eu/taxation_customs/resources/documents/taxation/gen_info/info_docs/tax_invento ry/list_minor_taxes_en.pdf (accessed 20th November, 2011)

European Commission (2011) “Taxes in Europe- Tax Reforms” database (TEDB/TAXREF) Taxation and Customs Union, European Commission, Brussels.

http://ec.europa.eu/taxation_customs/taxation/gen_info/info_docs/tax_inventory/index_en.htm (accessed 20th November, 2011)

European Migration Network (2011). Satisfying Labour Demand through Migration. European Migration Network, European Commission, Brussels

European Union Blue Card Network, "EU Blue Card” http://www.apply.eu/BlueCard/ (accessed $2^{\text {nd }}$ August, 2012)

Fosfuri, A., \& Motta, M. (1999), "Multinationals Without Advantages”, Scandinavian Journal of Economics, 101(4), 617-630

Glass, A., \& Saggi, K. (2002), "Multinational Firms and Technology Transfer”, Scandinavian Journal of Economics, 104(4), 495-513

Global Visas, Indian Work Permit, http://www.globalvisas.com/india_visas/indian_work_permit.html (accessed 22nd November, 2011)

Gray, P. (1985), "Multinational corporations and global welfare: an extension of Kojima and Ozawa”, Hitotsubashi Journal of Economics, 26, 125-133

Greenaway, D., Sousa, N., \& Wakelin, K. (2004), "Do Domestic Firms Learn to Export from Multinationals?”, European Journal of Political Economy, 20(4), 1027-1043

Grossman, G., \& Helpman, E. (2003), “Outsourcing vs FDI in Industry Equilibrium”, Journal of European Economic Association, 1, 317-327

Grossman, G., \& Helpman, E. (2004), "Managerial incentives and International organisation of Production”, Journal of International Economics, 63 , 237-262

Grubel, H. G., \& Scott, A. (1966), “The International Flow of Human Capital”, American Economic Review, 268-274

Hamilton, B., \& Walley, J. (1984), "Efficiency and Distributional Implications of Global Restrictions on Labor Mobility: Calculations and Policy Implications", Journal of Development Economics, 14(1), 61-75 
Hoekman, B., \& Saggi, K. (2000), "Assessing the Case for Extending WTO Disciplines on Investment-Related Policies”, Journal of Economic Integration, 629-653 http://www.workpermit.com/uk/uk.htm (accessed 25th September, 2011) http://www.globalvisas.com/germany_visa/german_work_visa.html (accessed 25th September 2011) http://www.globalvisas.com/visa_france/work_visa_france.html (accessed 25th September, 2011) http://www.parislawyer.fr/gifs/pdf/ComingtoWorkinFrance.pdf (accessed 25th September, 2011) http://www.immihelp.com/visas/schengenvisa/ (accessed 1st November, 2011) http://www.esteri.it/visti/home_eng.asp (accessed 25th September, 2011) http://www.mpimmigration.com/index.php?option=com_content\&view=article\&id=48\&Itemid=27 Milan (accessed 25th September, 2011)

Hummels, D., Ishii, J., \& Yi, K. (2001), "The nature and growth of vertical specialisation in World Trade”, Journal of International Economics, 54, 75-96

Hummels, D., Rapoport, D., \& Yi, K. (1998), "Vertical Specialisation and the changing nature of World Trade”, FRNBY Economic policy Review, 4, 79-99.

Indian Express (2003), "Nasscom Urges Dutch Govt. for fast solution of the I-Flex case”, March 30 http://www.indianexpress.com/oldStory/21097/ (accessed 20th December, 2011)

International Trade Centre, Investment Map, http://www.investmentmap.org/ (accessed $15^{\text {th }}$ April, 2012)

Investment and Technology Promotion Division (March 2007), "India- Dynamic Business Partner: Investor friendly Destination”, Ministry of External Affairs, Government of India, New Delhi. http://www.indiainbusiness.nic.in/Book.pdf (accessed 7th December, 2011)

Iredale, R. (2001), “The Migration of Professionals: Theories and Typologies”, International Migration, 39(5), 7-26

Iredale, R. (1999). The Need to Import Skilled Personnel: Factors Favouring and Hindering its International Mobility. International Migration, 37(1), 89-123

Johnson, H. (1967), “Some Economic Aspects of Brain Drain”, The Pakistan Development Review, $379-411$

Johnson, J. M., \& Regets, M. (1998), "International Mobility of Scientists and Engineers to the U.S.: Brain Drain or Brain Circulation?”, National Science Foundation Issue Brief, (pp. 98-316)

Kalinova, B., Palem, A., \& Thomsen, S. (2010), “OECD’S FDI Restrictiveness Index: 2010 Update”, OECD Working Papers on International Investment No. 2010/3 OECD Investment Division, Paris http://www.oecd.org/dataoecd/32/19/45563285.pdf (accessed $22^{\text {nd }}$ November, 2011)

Kokko, A., Zejan, M., \& Tansini, R. (2001), “Trade Regimes and Spillover Effects of FDI: Evidence from Uruguay”, Weltwirtschaftliches Archiv, 137(1), 124-149

Kumar, N. (2001), “WTO’s Emerging Investment Regime: Way Forward for Doha Ministerial Meeting”, Economic and Political Weekly, 36(33), 3151-3158

Markusen, J. (1984), "Multinationals, multi-plant economies, and the gains from trade", Journal of International Economics, 16, 205-226

Markusen, J., \& Maskus, K. (2001), "General-Equilibrium Approaches to the Multinational Firm: A Review of Theory and Evidence”, NBER Working Paper No.8334, Cambridge, USA

Markusen, J., \& Venables, A. (1999), "Foreign Direct Investment as a Catalyst for Industrial Development”, European Economic Review, 43, 335-356

McLaren, J. (2000), “Globalization and vertical structure”, American Economic Review, 90, 12391254 
Meyer, K. (2003), “FDI Spillovers in Emerging Markets: A Literature Review and New Perspectives”, DRC Working Paper No. 15, Centre for New and Emerging Markets, London Business School

Mills, J. (1929[1848]), Principles of Political Economy, London: Longman

Ministry of External Affairs (March, 2007), http://www.indiainbusiness.nic.in/Book.pdf) (accessed $7^{\text {th }}$ December, 2011)

Ministry of Overseas Indian Affairs, "Bilateral Agreements", Government of India, New Delhi http://moia.gov.in/services.aspx?id1=81\&idp=81\&mainid=73 (accessed 15th November, 2011)

Ministry of Overseas Indian Affairs, "Agreement between The Republic of India and The Federal Republic of Germany on Social Insurance", Government of India New Delhi http://www.moia.gov.in/pdf/SSAGermanyAgreementENG_final_INDAside.pdf (accessed 13th June, 2012)

Ministry of Overseas Indian Affairs, "Agreement on Social Security Between The Government of Republic of India And the The Government of the French Republic”, Government of India, New Delhi http://moia.gov.in/pdf/SSAFranceEng_versionforIndia.pdf (accessed 20th November, 2011)

Mody, A. (2004), “Is FDI Integrating the World Economy?”, The World Economy, 27(8), 1195-1222

Mountford, A. (1997), “Can a Brain Drain be Good for Growth in the Source Economy?”, Journal of Development Economics, 53(2), 287-303

Nunnenkamp, P., \& Pant, M. (2003), "Why the Case for a Multilateral Agreement on Investment Is Weak”, Kiel Discussion Papers. Kiel Institute for World Economics

OECD (2010), "International Migration and the United Kingdom" Report of the United Kingdom SOPEMI correspondent to the OECD, Paris

Ozawa, T. (1979), “A newer type of foreign investment in third world resource development”, Rivista Internazionale di Scienze Economiche e Commerciali, 29, 1133-1151

Ozawa, T. (1992), "Foreign Direct Investment and Economic Development”, Transnational Corporations, 1(1), 27-54

Panagariya, A. (1999), "The Millennium Round and Developing Countries: Negotiating Strategies and Areas of Benefits”, University of Maryland, College Park

Pollitt, H. (2009), “The E3ME Front End”, Cambridge Econometrics, Cambridge

Rodrik, D. (2002), “Feasible Globalizations”, Centre for Economic Policy Research Discussion Paper 3524, CEPR, London

Sinani, E., \& Meyer, K. (2004), "Spillovers of Technology Transfer from FDI: the Case of Estonia”, Journal of Comparative Economics, 32, 445-466

Stahl, C. (1993), "Explaining International Migration” in C.W. Stahl, R. Ball, C. Inglis and P. Gutman (eds.) Global population movements and their implications for Australia, Canberra: Australian Government Publishing Service

Straubhaar, T., \& Wolburg, M. (1998), "Brain Drain and Brain Gain in Europe: An Evaluation of East-European Migration to Germany”, CIIP and Institute for Global Conflict and Cooperation, Germany

Taylor, J. E., \& Adleman, I. (1995), Village Economies: The Design, Estimation and Use of VillageWide Economic Models. New York: Cambridge Press

Teferra, D. (2000), "Revisiting the Brain Mobility Doctrine in the Information Ages", Center for International Higher Education, Boston College 
United Nations (Feb 2001), "World Population Prospects 1950-2050", The 2000 Revision, United Nations, New York

US Government Accountability Office (February 2008), "Foreign Investment Laws and Policies Regulating Foreign Investment in 10 Countries” Report to the Honorable Richard Shelby, Ranking Member, Committee on Banking, Housing, and Urban Affairs, U.S. Senate, Washington, DC http://www.gao.gov/new.items/d08320.pdf (accessed 18th November, 2011)

Walmsley, T., \& Winters, L. (2005), "Relaxing the Restrictions on the Temporary Movement of Natural Persons: A Simulation Analysis”, Journal of Economic Integration, 20(4), 688-726

Wang, J., \& Blomström, M. (1992), “Foreign Investment and Technology Transfer: a Simple Model”, European Economic Review, 36, 137-155

Wise, H. M., "Coming to Work in France: French Work Visas Streamlined", http://www.parislawyer.fr/gifs/pdf/ComingtoWorkinFrance.pdf (accessed 4th November, 2011)

Worldwide Visa Bureau, India Visa, http://www.visabureau.com/worldwide/india-visa.aspx (accessed 22nd November, 2011)

World Bank, http://www.doingbusiness.org/ /media/FPDKM/Doing\%20Business/Documents/AnnualReports/English/DB07-FullReport.pdf (22nd November, 2011)

World Bank, http://www.doingbusiness.org/data (accessed 22nd November, 2011)

Yeats, A. (2001), “Just how big is global production sharing?”, in S. Arndt, \& H. Kierzkowski (eds.) Fragmentation: New production patterns in the world economy, Oxford University Press, USA

Young, A. (2000), “What Next for Labor Mobility under GATS?” in P. Sauve and R. M. Stern eds. GATS 2000: New Directions in Services Trade Liberalization, Brooking Institute Press, Washington, DC 